Full length Article

\title{
Tectono-stratigraphy of the Orhaniye Basin, Turkey: Implications for collision chronology and Paleogene biogeography of central Anatolia
}

\author{
A. Licht ${ }^{\mathrm{a}, \mathrm{b}, \mathrm{c}, *}$, P. Coster ${ }^{\mathrm{a}}$, F. Ocakoğlu ${ }^{\mathrm{d}}$, C. Campbell ${ }^{\mathrm{e}}$, G. Métais ${ }^{\mathrm{f}}$, A. Mulch ${ }^{\mathrm{g}, \mathrm{h}}$, M. Taylor ${ }^{\mathrm{e}}$, \\ John Kappelman ${ }^{\mathrm{i}}$, K. Christopher Beard ${ }^{\mathrm{a}, \mathrm{j}}$ \\ ${ }^{a}$ Biodiversity Institute, University of Kansas, Lawrence, KS 66045, USA \\ b Universität Potsdam, Institute of Earth and Environmental Science, 14476 Potsdam, Germany \\ ${ }^{c}$ Department of Earth and Space Sciences, University of Washington, Seattle, WA, USA \\ d Department of Geological Engineering, Eskişehir Osmangazi University, Eskişehir, Turkey \\ e Department of Geology, University of Kansas, Lawrence, KS 66045, USA \\ ${ }^{\mathrm{f}}$ CR2P, Paléobiodiversité et Paléoenvironnements, UMR 7207 (CNRS, MNHN, UPMC), Sorbonne Université, Muséum National d'Histoire Naturelle, 8 rue Buffon, 75005 \\ Paris, France \\ ${ }^{\mathrm{g}}$ Senckenberg Biodiversity and Climate Research Centre (BiK-F), Frankfurt, Germany

 \\ ${ }^{\mathrm{i}}$ Department of Anthropology, University of Texas, Austin, TX 78712, USA \\ ${ }^{j}$ Department of Ecology \& Evolutionary Biology, University of Kansas, Lawrence, KS 66045, USA
}

\section{A R T I C L E I N F O}

\section{Keywords:}

Anatolia

Eocene

Collision

Biogeography

\begin{abstract}
A B S T R A C T
Located along the İzmir-Ankara-Erzincan Suture (IAES), the Maastrichtian - Paleogene Orhaniye Basin has yielded a highly enigmatic -yet poorly dated- Paleogene mammal fauna, the endemic character of which has suggested high faunal provincialism associated with paleogeographic isolation of the Anatolian landmass during the early Cenozoic. Despite its biogeographic significance, the tectono-stratigraphic history of the Orhaniye Basin has been poorly documented. Here, we combine sedimentary, magnetostratigraphic, and geochronological data to infer the chronology and depositional history of the Orhaniye Basin. We then assess how our new data and interpretations for the Orhaniye Basin impact (1) the timing and mechanisms of seaway closure along the IAES and (2) the biogeographic evolution of Anatolia.

Our results show that the Orhaniye Basin initially developed as a forearc basin during the Maastrichtian, before shifting to a retroarc foreland basin setting sometime between the early Paleocene and $44 \mathrm{Ma}$. This chronology supports a two-step scenario for the assemblage of the central Anatolian landmass, with incipient collision during the Paleocene - Early Eocene and final seaway retreat along the IAES during the earliest Late Eocene after the last marine incursion into the foreland basin. Our dating for the Orhaniye mammal fauna (44-43 Ma) indicates the persistence of faunal endemism in northern Anatolia until at least the late Lutetian despite the advanced stage of IAES closure. The tectonic evolution of dispersal corridors linking northern Anatolia with adjacent parts of Eurasia was not directly associated with IAES closure and consecutive uplifts, but rather with the build-up of continental bridges on the margins of Anatolia, in the Alpine and Tibetan-Himalayan orogens.
\end{abstract}

\section{Introduction}

Reconstructing the chronology of oceanic basin closures and subsequent collisions between the main crustal units of Turkey and the easternmost Mediterranean region is a prerequisite for any paleogeographic or paleotectonic understanding of the broader AlpineHimalayan orogen. The mechanisms and precise timing for the final assemblage of the Anatolian landmass during the Paleogene remain controversial, despite a growing amount of tectonic reconstructions (Sengör and Y1lmaz, 1981; Görür et al., 1998; Okay and Tüysüz, 1999; Rice et al., 2006; Barrier and Vrielynck, 2008; Robertson et al., 2009; Kaymakç1 et al., 2009; van Hinsbergen et al., 2010, 2016; Menant et al., 2016). Recent studies suggest that the tectonic development of Anatolia may play a role in the dispersal of mammal faunas. Available data from fossil mammals indicate a high degree of endemism for Anatolian terrestrial vertebrate faunas during much of the early Paleogene

\footnotetext{
* Corresponding author at: Department of Earth and Space Sciences, University of Washington, Seattle, WA, USA.

E-mail address: licht@uw.edu (A. Licht).
} 


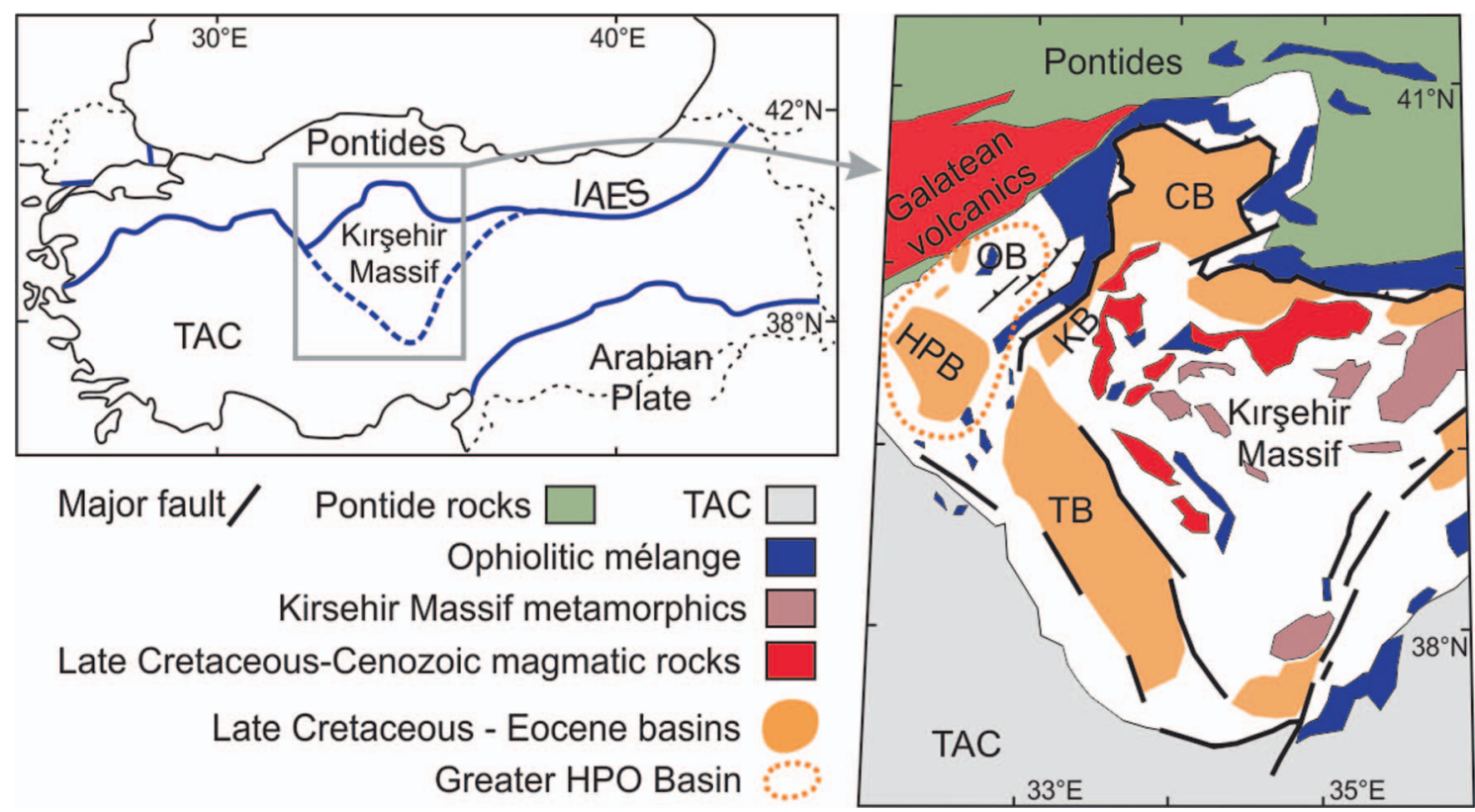

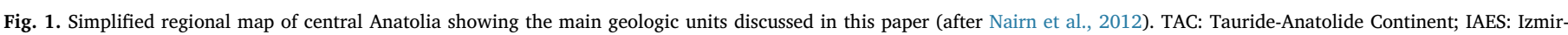

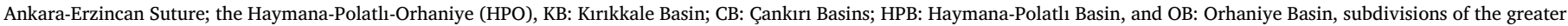
HPO (Haymana-Polatll-Orhaniye) Basin (Koçyiğit, 1991).

(Kappelman et al., 1996; Maas et al., 1998, 2001; Métais et al., 2012, 2017; Sanders et al., 2014; Erdal et al., 2016). The provincialism shown by Turkish lower Paleogene mammal faunas presumably reflects a long history of paleogeographic and paleobiogeographic isolation, perhaps punctuated by the formation of ephemeral land bridges and/or episodes of sweepstakes dispersal with adjacent parts of Africa, Europe, and Asia (Kappelman et al., 1996; Maas et al., 1998, 2001; Chaimanee et al., 2012; Şen, 2013).

The most extensive Paleogene oceanic basin closure zone of the eastern Mediterranean region is the Izmir-Ankara-Erzincan Suture (IAES), which trends roughly east-west for over $1750 \mathrm{~km}$ from western Turkey to Iran (Sengör and Yllmaz, 1981; Menant et al., 2016). The IAES zone marks the former position of the northern Neotethys Oceanic subduction zone as indicated by the genesis of ophiolites, accretionary prisms, volcanic arcs, and associated basins during Cretaceous-Paleogene time (Nairn et al., 2012; Fig. 1). The IAES zone separates the Pontide terrane in northern Anatolia, which is an elongated microcontinent separated from Eurasia during the opening of the Black Sea (Sengör and Yilmaz, 1981; Görür, 1988), from the Tauride-Anatolide continent (TAC) in southern Anatolia, which is a fold and thrust belt with ophiolites, platform carbonates, and different African-derived metamorphosed units (Robertson et al., 2013). In central Anatolia, the IAES zone straddles the Kirşehir Massif (Fig. 1), generally viewed as separated from the TAC by a deep basin that may (Lefebvre et al., 2013; Menant et al., 2016) or may not (Gülyüz et al., 2013; Advokaat et al., 2014; van Hinsbergen et al., 2016) have been oceanic, and that is frequently referred to as intra-Tauride basin, or ocean.

The timing and mechanisms of oceanic closure between the Pontide terrane and the Kirşehir Massif along the IAES zone are still debated. Oroclinal bending of the central Pontides since the latest Cretaceous is consistent with the indentation of the Kirşehir Massif and onset of collision during Maastrichtian - earliest Paleocene times (Kaymakçı et al., 2000; Meijers et al., 2010). Exhumation of the Kirşehir Massif might have started as early as the middle Paleocene (57-62 Ma), as recorded in apatite fission track ages from Kirşehir granitoids (Boztuğ and Jonckheere, 2007), although extension in other parts of the Kirşehir block is recorded until the middle Eocene (Advokaat et al., 2014). Subsidence and deposition of marine sedimentary sequences from Maastrichtian to latest Lutetian time (43-41 Ma) in a string of basins -namely the Haymana-Polatli-Orhaniye (HPO), Kirikkale, and Çankiri basins- along the suture zone suggests the persistence of a continuous seaway separating the Pontide terrane from the Kirşehir Massif (Görür et al., 1998; Eraslan, 2006; Nairn et al., 2012; Dinçer, 2016). Three collisional scenarios have been proposed to explain the persistence of basin development and marine incursions along the IAES until the late Eocene. (1) One of the earlier tectonic models suggests these basins developed as remnant forearc basins preserved during diachronous collision and incomplete closure of the suture zone (Görür et al., 1998); the onset of collision occurred first at the northern apex of the Kirşehir massif during the latest Maastrichtian, with subduction continuing in other parts of the suture zone until final closure of the IAES and the onset of southward thrusting of the Pontides over the TAC in the late to middle Eocene along the entire suture zone (Koçyiğit, 1991; Görür et al., 1998). (2) Alternatively, the basins are thought to be isolated piggy-back basins formed above overthrust nappes on the TAC (Gürer and Aldanmaz, 2002); this scenario implies complete closure of the IAES since the Maastrichtian, and local, post-collisional extensional processes are thought to explain basin development (Cemen et al., 1999). (3) More recently, tectono-stratigraphic studies highlight a complex deformation history suggesting syn-deformation deposition along the IAES zone: the Çankiri Basin appears to have been deformed and partitioned since the Paleocene into a series of smaller piggy-back basins with typical foreland basin sequence in-fillings (Kaymakç1 et al., 2009); similarly, the Kirikkale Basin has been folded and structurally partitioned since at least the late Paleocene (Nairn et al., 2012). This chronology for closure of the IAES suggests an incipient (i.e., 'soft') collision since the late Maastrichtian - Paleocene followed by final closure (i.e., 'hard collision') during the latest Lutetian (Rice et al., 2006; Nairn et al., 2012).

In this context, the tectono-stratigraphic history of the HPO Basin remains enigmatic. The HPO Basin is commonly divided into two subbasins, the Haymana-Polatli sub-basin to the southwest and the Orhaniye sub-basin to the northeast (Fig. 1; Koçyigit, 1991). Whereas in the Haymana-Polatli sub-basin, most of the deposits predating the uppermost Lutetian are dominated by deep marine turbidite sequences, Paleocene-Eocene deposits in the Orhaniye sub-basin dominantly consist of continental clastic rocks (e.g., redbeds; Koçyigit et al., 1988; Koçyigit, 1991). Early tectono-stratigraphic studies have thus 
interpreted both sub-basins as representing different sides of a larger HPO forearc basin developed along the Pontide active margin, with the Orhaniye sub-basin being its peripheral part emphasizing continuous forearc-style deposition until at least the latest Lutetian (Görür et al., 1984; Gökten et al., 1988; Koçyigit et al., 1988; Koçyigit, 1991). This scenario is poorly constrained by stratigraphic relationships and remains debated (Ocakoğlu and Çiner, 1995) because most of the lithologic units of the HPO Basin lack appropriate geochronological constraints.

Continental clastic sediments of the Orhaniye sub-basin have yielded the most diverse and enigmatic Paleogene mammal fauna known so far from central Anatolia (Kappelman et al., 1996; Maas et al., 1998, 2001). The high degree of endemism shown by this fauna is thought to result from paleogeographic isolation of central Anatolia during much of the Paleogene, significantly weakening mammalian biostratigraphy as a reliable correlation tool (Maas et al., 2001; Şen, 2013; Erdal et al., 2016). Refining the stratigraphy and geochronology of the Orhaniye sub-basin is therefore critical for developing a regional biostratigraphy for the Anatolian Paleogene, and for understanding the evolution of terrestrial mammal faunas at the crossroads of the European, Asian, and African biogeographic provinces.

This study documents the chronology and the tectono-stratigraphic context of the Orhaniye sub-basin in order to (1) test the different collisional scenarios along the IAES, and (2) refine the chronology of oceanic basin closure, suture zone development, and possible land bridge connections in Anatolia. We combine sedimentary, structural, and geochronological evidence to infer the depositional history of the Orhaniye sub-basin and relate it to structural partitioning of the basin and the tectonic evolution of the greater HPO Basin. Finally, these various geologic relationships help to refine our knowledge of the biogeography of Central Anatolia.

\section{Geological context}

\subsection{The HPO basin}

The HPO Basin is located at the juncture where the Pontide terrane, the TAC and the Kurşehir Massif meet (Görür et al., 1984; Fig. 1). The northern margin of the HPO basin is bounded by Pontide affinity rocks to the north, including metamorphosed pre-Jurassic basement (the 'Karakaya Complex'; Şengör et al., 1984), Jurassic to lower Cretaceous carbonate rocks (Altiner et al., 1991), and Cretaceous to Miocene volcanic rocks of the Galatean arc (Sengör and Y1lmaz, 1981; Görür et al., 1984; Koçyiğit, 1991). To the south, the HPO Basin is bounded by the North Anatolian Ophiolitic Melange (NAOM), which is a chaotic tectono-sedimentary mixture made up of detached blocks of Mesozoic ultramafic rocks, radiolarites, and limestones formed in the accretionary wedge setting of the north-dipping Neotethys subduction zone below the Pontides (the Ankara Accretionary Complex; Rojay, 2013). To the southeast, the NAOM overlies granitoids, ophiolites, and metamorphosed rocks of the Kırşehir Massif (Akiman et al., 1993; Whitney et al., 2001; Advokaat et al., 2014). To the south-southeast, the NAOM overlies the Maastrichtian-Pliocene Tuzgölü Basin, which has been interpreted as a remnant forearc/foreland basin formed by the collision between the TAC and an independent Kırşehir Block (Görür et al., 1984, 1998; Nairn et al., 2012), Alternatively, the Tuzgölü Basin may be an intracontinental, fault-controlled basin that formed in response to post-collisional extension of a unified TAC-Kırşehir Massif landmass (Cemen et al., 1999; van Hinsbergen et al., 2016). To the southwest, the NAOM overlies TAC metamorphosed rocks and carbonate rocks (Pourteau et al., 2010; Robertson et al., 2013).

The HPO Basin is commonly interpreted to be an accretionary forearc basin of the Pontide margin, developed on the Ankara Accretionary Complex, between the Galatean arc and the subduction zone trench (Görür et al., 1984, 1998; Koçyiğit, 1991; Nairn et al., 2012). The complete forearc sequence is preserved in the Haymana-
Polatlı area (southwest side of the basin; Görür et al., 1984), where deposits are the thickest $(>5 \mathrm{~km})$ and dominated by deep-marine facies (Ünalan et al., 1976; Koçyiğit, 1991). The base of the sedimentary sequence starts with upper Campanian-Maastrichtian turbidites with frequent debris flows and olistostromes (Haymana Formation; Görür et al., 1984; Nairn et al., 2012); continuous, deep-marine turbiditic deposition is dominant for most of the Paleocene and the Lower to Middle Eocene (Kırkkavak and Eskipolatlı Formations), with shallow marine carbonates (Çaldağ Formation) and continental red clastic rocks (Kartal Formation) along the basin's northern and western margins (Görür et al., 1984; Koçyigit, 1991). The sequence terminates with the upper Lutetian Çayraz Formation, a nummulitic shallow marine carbonate platform that laterally grades into continental red clastic rocks (Görür et al., 1984; Çiner et al., 1996; Dinçer, 2016). Locally, the sedimentary sequence is cut by local thrust faults juxtaposing NAOM rocks over the sedimentary basin, and occasionally Mio-Pliocene red beds and evaporites unconformably overlie the basin rocks (Görür et al., 1984).

\subsection{The Orhaniye 'peripheral' sub-basin}

To the northeast of the Haymana-Polatl area, at the interface between the Pontides and the Kırşehir Massif, the Ankara Accretionary Complex is more exhumed and most of the forearc sequence is missing (Fig. 1; Rojay, 2013). The map pattern of Upper Cretaceous - Middle Eocene rocks of the HPO Basin define a northeast-southwest trending syncline - the Kazan syncline, over a map distance greater than $40 \mathrm{~km}$ (Fig. 2). Deposits in this area are thinner and dominated by shallow marine to continental clastics (Kazanc1 and Gokten, 1986). The complete Upper Cretaceous-Eocene sequence is preserved and is wellexposed on the southern limb of the syncline, locally in a smaller northwest-southeast trending anticline covering an approximately rectangular $15 \times 5 \mathrm{~km}$ quadrant that includes the Orhaniye, Güvenç, Sarıbeyler, and Memlik villages, here referred to as the 'Orhaniye quadrant' (Fig. 2). Several names have been proposed for the different rock units comprising this sequence (hereafter referred to as the 'Orhaniye sequence') (Gökten et al., 1988; Koçyiğit et al., 1988; Ocakoğlu, 1991; Duru and Aksay, 2002). Here we follow the stratigraphic nomenclature of Gökten et al. (1988).

The Orhaniye sequence (Fig. 3) depositionally overlies a thick slice of the NAOM, mainly consisting of ophiolites, pillow-lavas, and olistostromes of Upper Jurassic-lower Campanian turbidites, carbonates and radiolarites (Koçyiğit, 1991; Rojay, 2013). The Orhaniye sequence starts with the Maastrichtian - lower Paleocene (?) 200-850 m thick Dikmendede Formation, consisting of deep-marine turbidites (Özkan and Bozdag, 2009, 2011). The base of the Dikmendede Formation unconformably overlies the NAOM and begins with $\sim 60 \mathrm{~m}$ of a conglomeratic sequence composed of reworked ophiolites and olistostromes; it then grades into alternating sequence of green turbiditic sandstones, shales and marls making up most of the unit with a typical Maastrichtian foraminiferal assemblage (Sağular, 1986). The flysch eventually grades upsection into unfossiliferous red sandstones and conglomerates, which make up the upper $\sim 100$ meters of the Dikmendede Formation and are interpreted as being deposited in a shallowing deltaic environment ('Kuşkonan Formation' of Ocakoğlu, 1991; 'Kartal Formation' of Koçyiğit, 1991). Locally, the Dikmendede Formation is intruded by dikes and sills of the Orhaniye syenite, an undated shoshonitic intrusion commonly attributed to the Paleocene and associated with early Galatean arc volcanism (Tokay et al., 1988; Koçyiğit, 1991).

The Dikmendede Formation and associated intrusions are disconformably overlain by the Paleocene (?) - Middle Eocene (?) Uzunçarşıdere Formation (Ocakoğlu, 1991). The Uzunçarşıdere Formation consists of $100-500 \mathrm{~m}$ of sandstones, pedogenic red mudstones, and alternating layers of carbonate/shale that have been interpreted as representing a coastal to lagoonal environment (Koçyigit et al., 1988; 




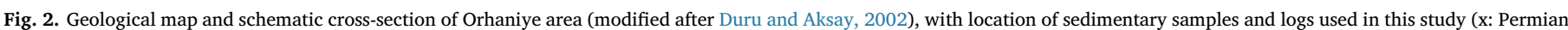
metasandstone; z: Pazar Paleogene volcaniclastics; 1-6: sedimentary logs of Fig. 5).

\section{Koçyigit, 1991).}

The Uzunçarşıdere Formation is in sharp contact with the overlying 100-300 m thick Orhaniye Formation, which is mostly made of nummulitic limestones (Ocakoğlu, 1991; Koçyiğit, 1991). The Orhaniye Formation is attributed to the uppermost Lutetian - lowermost Bartonian (Shallow Benthic Zones 14-17, 43 to 38 Ma; Eraslan, 2006; Deveciler, 2014). It correlates to the Çayraz Formation in the HaymanaPolatlı area (Çiner et al., 1996; Dinçer, 2016) and the Kocaçay Formation in the Cankırı Basin (Kaymakçı et al., 2009), all of which correspond to the last marine incursion along the IAES (Rice et al., 2006).

This Cretaceous - Eocene sedimentary sequence is thought to reflect the northernmost, peripheral part of the HPO Basin, based on lithofacies description and local stratigraphic correlations (Koçyiğit, 1991; Görür et al., 1998). Alternatively, it may represent an isolated, smaller basin perched on the accretionary wedge based on similar approaches (Ocakoglu and Çiner, 1995). The Cretaceous-Paleogene sedimentary sequence is overlain by $\sim 400 \mathrm{~m}$ of post-Eocene continental molasse, including the Upper Eocene (?) - Miocene (?) Parmaklık Formation and the Pliocene Akkaya Formation, all rich in lacustrine carbonates (Gökten et al., 1988; Ocakoğlu and Çiner, 1995). The successive contacts between these three units are locally disconformable (Gökten et al., 1988; Koçyigit, 1991).

\subsection{The Uzunçarşıdere formation and its problematic fauna}

The Uzunçarşıdere Formation is commonly divided into three members: the Lülük (lower), Gökdere (middle), and Sarıbeyler (upper) members (Ocakoğlu, 1991). The Lülük member is made of diagnostic red to brown clastic rocks consisting of wing-shaped conglomerate and sandstone bodies and caliche-bearing mudstones (Ocakoğlu and Çiner, 1995; Ocakoğlu, 1998). The Gökdere member sharply overlies the Lülük member and is dominated by finer-grained green mudstones and lacustrine carbonates with episodic wing-shaped sandstone bodies and brown to purple pedogenised mudstones; it progressively grades into the Sarıbeyler member, a widespread and thick (200-400 m) unit comprising cyclic carbonate-mudstone alternations (Ocakoğlu and Çiner, 1995; Ocakoğlu, 1998). On the western side of the Kazan syncline, in the vicinity of Kınık village (Fig. 2), the Uzunçarşıdere Formation consists of lacustrine, trona-bearing deposits that directly overlie Pontide basement rocks (here the Karakaya metamorphic complex and Callovian-Oxfordian limestones (Duru and Aksay, 2002).

Dating the Uzunçarşıdere Formation is problematic. Initially, the unit was correlated with the Kırkkavak and lower Eskipolatl Formations of the Haymana-Polatlı area and was attributed to the Upper Paleocene and Lower Eocene (Ünalan et al., 1976; Gökten et al., 1988; Koçyiğit, 1991). Foraminiferal assemblages from the underlying and overlying Dikmendede and Orhaniye Formations indicate a broad potential stratigraphic range, spanning from the Maastrichtian to the uppermost Lutetian (see references above). More recent findings of fossil mammals (marsupials, embrithopods, pleuraspidotheriids) in the Lülük member suggest a late Paleocene to early Middle Eocene age for the lower part of the formation (Kappelman et al., 1996; Maas et al., 2001; Erdal et al., 2016; Métais et al., 2017). The endemic character of the mammalian fauna currently known from the Uzunçarşıdere Formation requires that any biostratigraphic assessment of its age be treated with caution. The high degree of endemism in the mammalian fauna from the Uzunçarşıdere Formation indicates long-term isolation of the Pontides, perhaps suggesting a pre-collisional context for the Uzunçarşıdere Formation. Dating the Uzunçarşıdere fauna by alternative, nonbiostratigraphic methods is thus particularly critical. In a preliminary report, Kazanc1 et al. (2001) mentioned a tuff in the Gökdere member having an age of $45.7 \mathrm{Ma}$, yet do not provide details of dating methods, age uncertainty, sampling locality, and stratigraphic level. 




Fig. 3. Simplified stratigraphic section of the Orhaniye sequence (Orhaniye Quadrant), after Gökten et al. (1988) and Koçyiğit (1991).

\section{Material and methods}

During the 2014 and 2015 summer seasons, we mapped, described and sampled outcrops of the Orhaniye sequence on both sides of the Kazan syncline, paying special attention to the Uzunçarşıdere Formation in the Orhaniye quadrant. We refined the initial map of Duru and Aksay (2002) and completed the dataset of stratigraphic logs provided by Ocakoğlu (1991) and Ocakoğlu and Çiner (1995) by additional logs, measured with $10 \mathrm{~cm}$ precision. Paleoflow directions were measured on sandstone trough cross-bedding on 3D outcrops, according to standard field methods (Collinson and Thompson, 1989).

Eight sandstone samples were selected along the Lülük Tepe section (Fig. 4; log. 3 in Fig. 2) to determine their contents in quartz, feldspar and lithic grains; thin sections were prepared at the Institut für Erd und Umweltwissenschaften (Potsdam, Germany); 300 points were then counted according to the Gazzi-Dickinson method (Dickinson, 1985). 45 carbonate samples were selected along the same section; thin sections were prepared to check the preservation of primary micrite. They were then digested in orthophosphoric acid and analyzed as $\mathrm{CO}_{2}$ in continuous flow mode using a Thermo MAT 253 mass spectrometer interfaced to a Thermo GasBench II at the Institute of Geosciences (University of Frankfurt, Germany). Raw isotopic ratios were calibrated against two in-house standards (made of Carrara marble and Merck commercial carbonate) as well as against NBS18 carbonate reference material. Final isotopic ratios are reported against V-PDB standard. Overall analytical uncertainties on the isotopic ratios are better than $0.11 \%$ absolute. Detailed methods for sample preparation and analysis can be found in Lüdecke et al. (2013).

Rock samples for magnetostratigraphic dating were collected from 22 levels along the same sedimentary section using a portable gasolinepowered drill and oriented in situ with a magnetic compass. Four to six separately oriented samples were collected from each stratigraphic level. The vertical spacing between sample levels ranged from 5 to $20 \mathrm{~m}$, depending on exposure conditions. Oriented block samples were collected from stratigraphic levels not favorable for drilling and were drilled in the laboratory. Paleomagnetic analyses of the samples were undertaken at the Institute for Geophysics, Jackson School of Geosciences (University of Texas, Austin, USA). Measurements of remanent magnetization were done using a three-axis cryogenic magnetometer (2G model). Following initial Natural Remanent Magnetization (NRM) measurements, samples were thermally demagnetized from $50{ }^{\circ} \mathrm{C}$ to $700{ }^{\circ} \mathrm{C}$ with increments of $25^{\circ} \mathrm{C}$. Demagnetization results were analyzed using the paleomagnetic data browser and analyzer PaleoMag 3.1. (Jones, 2002). The characteristic remanent directions were determined by principal component analysis (Kirschvink, 1980). We calculated site mean directions using Fisher (1953) statistics on virtual geomagnetic poles (VGPs) following procedures described in Deenen et al. (2011) and a $45^{\circ}$ cutoff was applied to the VGPs (Johnson et al., 2008). Analyses were carried out with the open-source software paleomagnetism.org (Koymans et al., 2016).

Five sandstone samples were selected for U-Pb dating of detrital zircons, including one Permian metasandstone of the Pontide basement (sample 15KZ01, location $\mathrm{x}$ in Fig. 2), one Paleogene volcaniclastic (sample PAZ4, location $\mathrm{z}$ in Fig. 2), and three sandstones from the Lülük Tepe section for the Dikmendede Formation (sample LT-10; stratigraphic level $20 \mathrm{~m}$ ), Lülük member (sample LT20; stratigraphic level $50 \mathrm{~m}$ ) and Sarıbeyler member (sample LT186; stratigraphic level $236 \mathrm{~m}$ ) of the Uzunçarşıdere Formation. Zircon crystals were extracted by traditional methods of heavy mineral separation at the Arizona LaserChron centre and at the Department of Geology, University of Kansas. U-Pb ages were generated using laser-ablation multi-collector inductively-coupled-plasma mass-spectrometry (LA-MC-ICPMS) with a laser spot diameter of $30 \mu \mathrm{m}$ at the LaserChron and $20 \mu \mathrm{m}$ at the University of Kansas. Detailed methods for extraction, analysis, and data reduction at both institutes can be found in Licht et al. (2016) and Nie et al. (2014). Maximum depositional age for detrital samples and crystallization age for volcanic samples were calculated using TuffZirc (Ludwig, 2003). The final age error calculated for each sample is the quadratic sum of the uncertainty of TuffZirc age calculation and of the systematic uncertainty during each session $(\sim 1 \%)$.

Detailed grain-counting results and stable isotope values are given in Supplementary Tables 1 and 2; paleomagnetic results are given in Supplementary Table 3; U-Pb data are given in Supplementary Table 4.

\section{Results}

\subsection{Stratigraphy of the Uzunçarşıdere formation}

Figs. 4 and 5 display a detailed log of the Uzunçarşıdere Formation with a resolution of $\sim 1 \mathrm{~m}$, displaying the Lülük, Gökdere, and Sarıbeyler members (Lülük Tepe section, location in Fig. 3; picture in Fig. 6a), and six more logs with a vertical resolution of $\sim 10 \mathrm{~m}$, following a northeast-southwest trend. The contact surface between the Dikmendede Formation and the Uzunçarşıdere Formation is irregular, and the uppermost $\sim 100 \mathrm{~m}$ of the Dikmendede Formation 


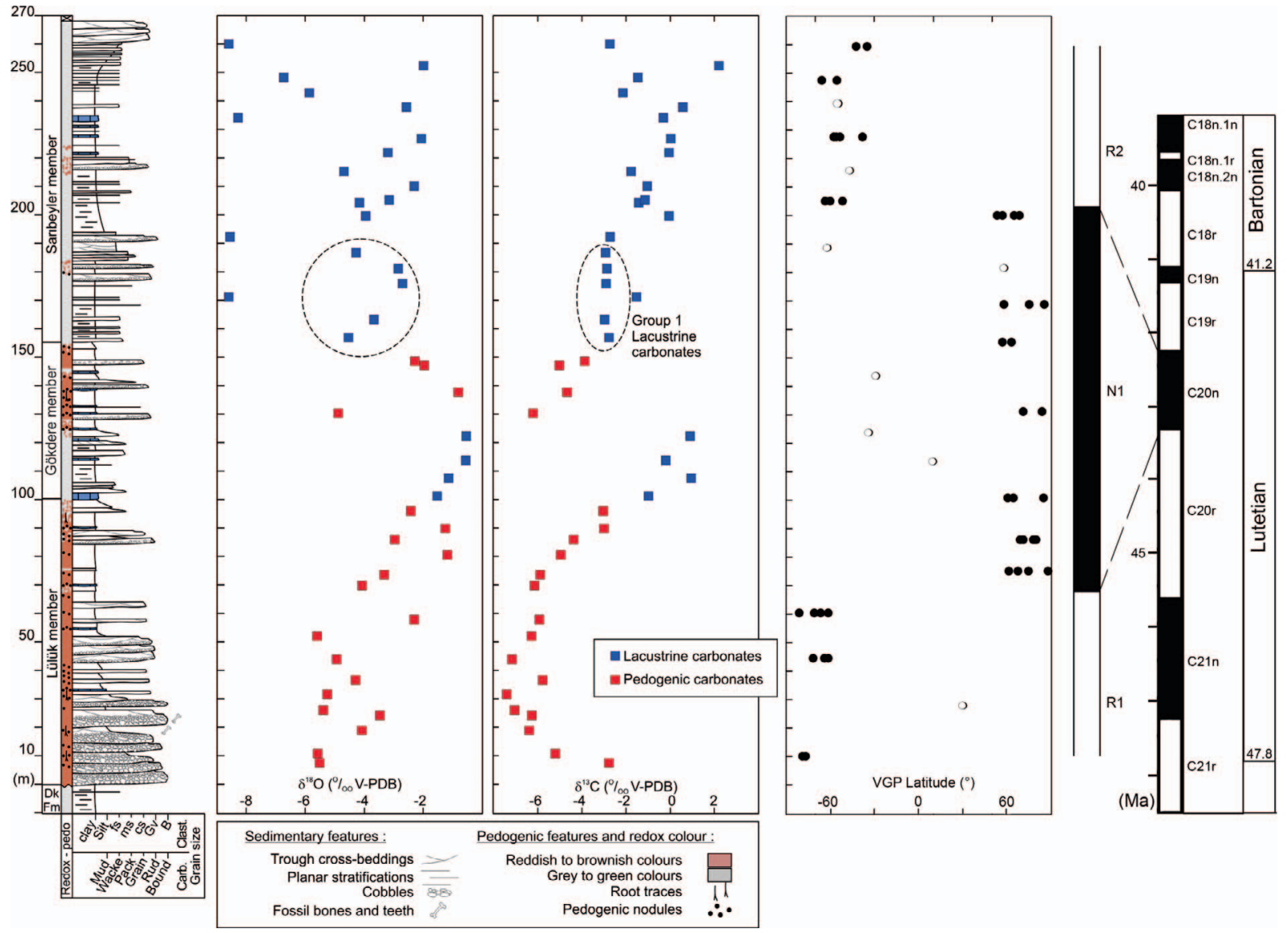

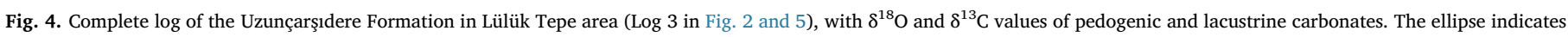

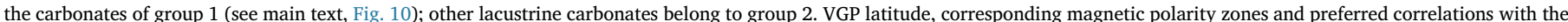

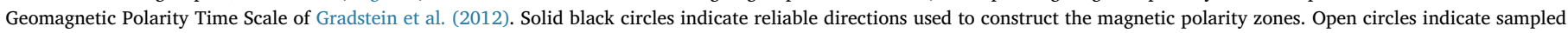
sites that had a $95 \%$ confidence interval $\left(\alpha_{95}\right)$ between samples larger than $30^{\circ}$ and were rejected for further analysis.

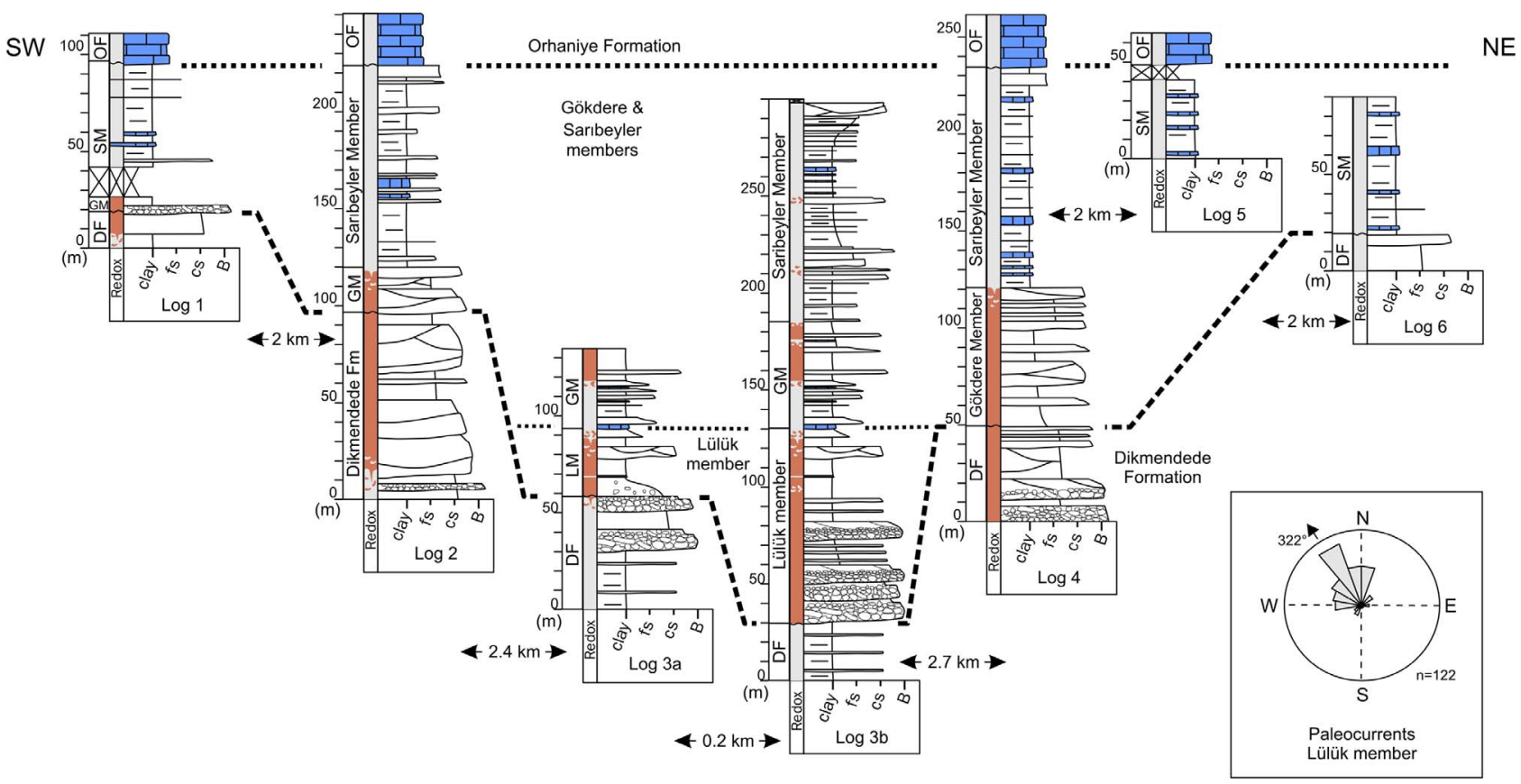

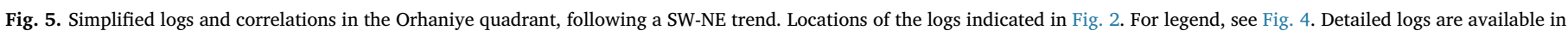

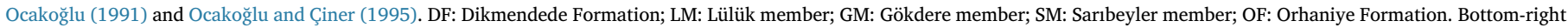
panel: paleocurrents measured in sandstones bodies of the Lülük member. 

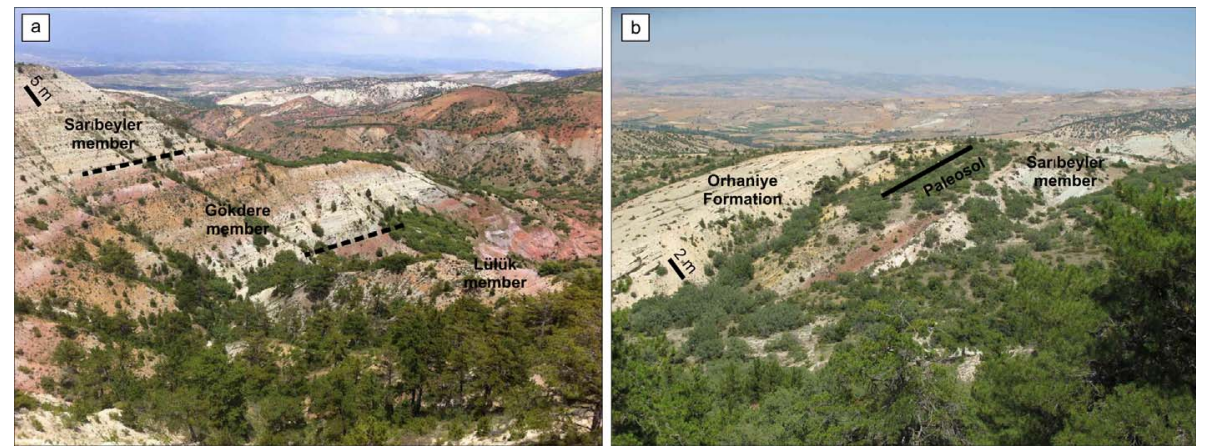

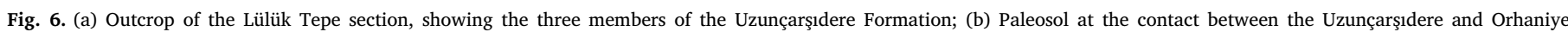
Formations, near Güvenç village.

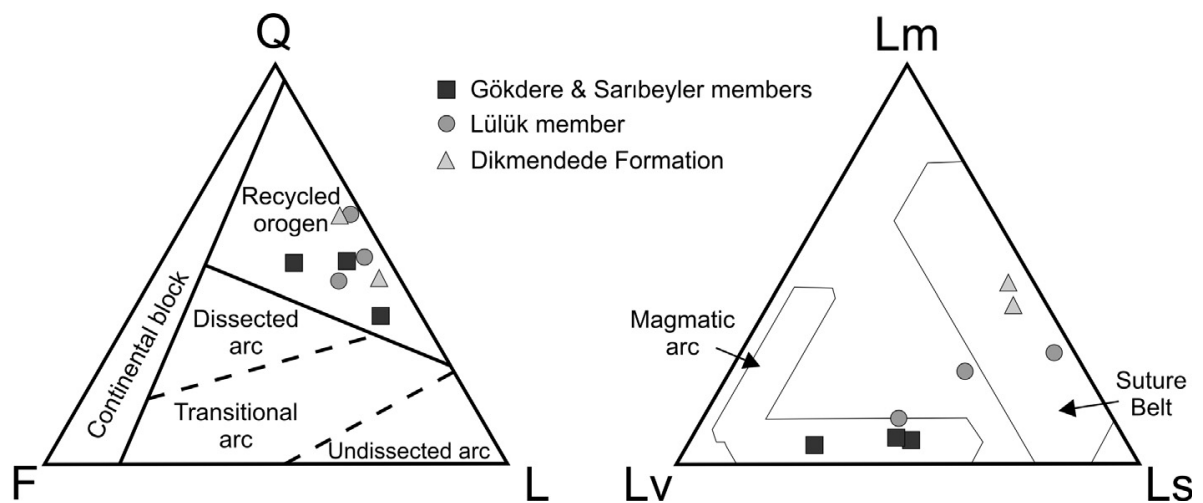

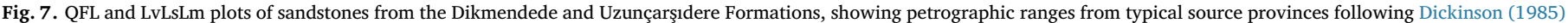
and Najman (2006). Q, quartz; F, feldspar; L, lithic fragments (Lm, metamorphic; Ls, sedimentary; Lv, volcanic).

consists of red deltaic sandstones that have only been preserved on the rim of the Orhaniye quadrant. The basal member of the Uzunçarşıdere Formation -the Lülük member- is only present in the core of the Orhaniye quadrant, where the uppermost layers of the Dikmendede Formation have been completely removed, indicating the in-filling of an incised paleo-landscape. The contact surface between the Dikmendede Formation and the Lülük member is commonly erosional, and the sequence starts with $\sim 10 \mathrm{~m}$ of grain-supported conglomerates made of reworked clasts from the Dikmendede Formation. In places, the contact is non-erosive, and is marked by a $1 \mathrm{~m}$ thick type- 4 caliche (sensu Gile et al., 1966) overlain by $\sim 5$ to $10 \mathrm{~m}$ of matrix-supported, pedogenised conglomerates. The remaining thickness of the Lülük member is made of wing-shaped sandstone bodies and type- 1 to type- 3 caliche-bearing red mudstones. Both of these environments yield mammalian fossils, sometimes preserved in carbonate nodules. Paleoflow measurements on trough cross-bedding show an unequivocal unimodal northwestward direction (Fig. 5).

The transition between the Lülük and Gökdere members is marked by the development of a 4-8 $\mathrm{m}$ thick pedogenic profile marked by nodules, root traces and increased bleaching in the upper horizons, and is capped by a $2-\mathrm{m}$ thick continuous carbonate layer. This carbonate layer is micritic, laminated, with occasional burrows, and is interpreted as the first lacustrine limestone of the section. The Gökdere member is a composite member made of these lacustrine limestones, grey laminated mudstones and shales, wing-shaped fine-grained sandstone bodies, and type-1 to type-2 caliche-bearing paleosols. The transition to the upper Sarıbeyler member of the Uzunçarşıdere Formation is both lateral and vertical, and characterized by the progressive disappearance of wingshaped sandstone bodies and paleosols, resulting in a shale and lacustrine limestone sequence. In this sense, the primary distinction between the Gökdere and Sarıbeyler members is only based on facies; both are interpreted as reflecting the proximal (fluvial to shallow lacustrine) and distal (deep lacustrine) facies of the same lacustrine sedimentary system. When the Lülük member is absent, the Gökdere/ Sarıbeyler members directly onlap the Dikmendede Formation.

To the southwest of the Orhaniye quadrant, $\sim 10 \mathrm{~km}$ on the other side of the Kazan syncline, the Uzunçarşıdere Formation consists of lacustrine deposits with facies similar to the Sarıbeyler member, with occasional trona deposits in its most basal part. The Uzunçarşıdere Formation thins dramatically toward the northeast and southwest of the Orhaniye quadrant (Fig. 5), the only location where the Lülük member can be seen. At $\sim 20 \mathrm{~km}$ to the northeast of the quadrant, the standard three members of the Uzunçarşıdere Formation are missing and replaced by undated Paleogene volcanic conglomerates and pyroclastics comprised mostly of andesite, trachyandesite, and basalt (Duru and Aksay, 2002). A $700 \mathrm{~m}$ section of these volcaniclastics is observed near Pazar (Fig. 2).

The contact between the Uzunçarşıdere Formation and the overlying Orhaniye Formation is locally concordant, but a slight angular disconformity is observed on both sides of the Kazan syncline. A 1-3 m thick brownish paleosol profile is locally preserved, developed below the contact, in the uppermost layers of the Sarıbeyler member (Fig. 6b).

\subsection{Sandstone petrography and $U-P b$ zircon age distributions}

Grain counting results for sandstones of the Dikmendede and Uzunçarşıdere Formations are displayed in Fig. 7. All samples are made of quartzolithic to lithoquartzose detritus and plot in the recycled orogen province on the QFL plot of Dickinson (1985). Lithic grains in the sandstones from the Dikmendede Formation are equally made of sedimentary and metamorphic fragments with very little volcanic detritus ( $<10 \%$ of the total lithic grains), as commonly seen in suture belts (Najman, 2006). By contrast, lithic grains from the Gökdere/ Saribeyler members are prominently volcanic $(45-70 \%$ of the total lithic grains). Volcanic lithic content of the Lülük member is intermediate between those of the Dikmendede Formation and Gökdere/ 


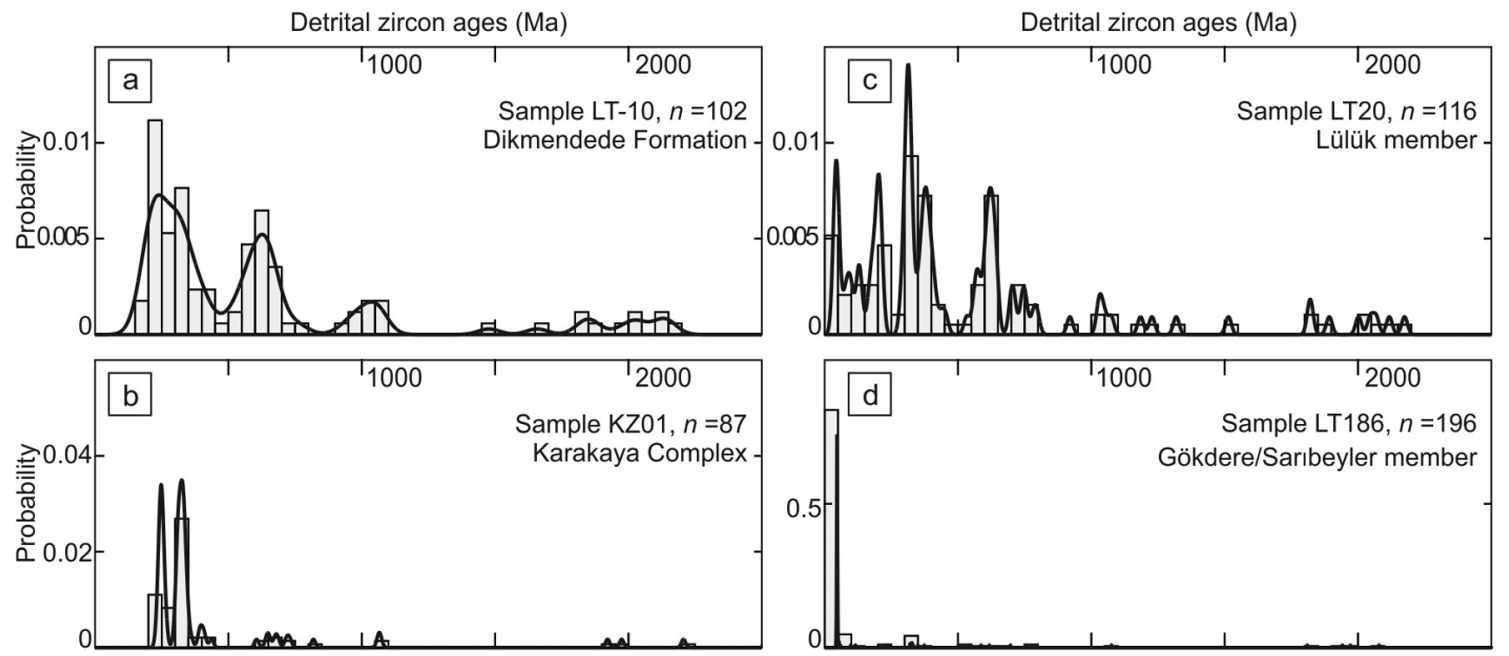

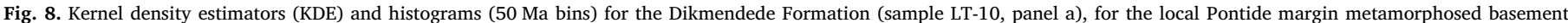

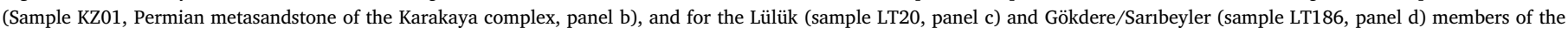
Uzunçarşıdere Formation. The kernel density bandwidth of each plot was determined with plug-in bandwidth selection method of Botev et al. (2010).

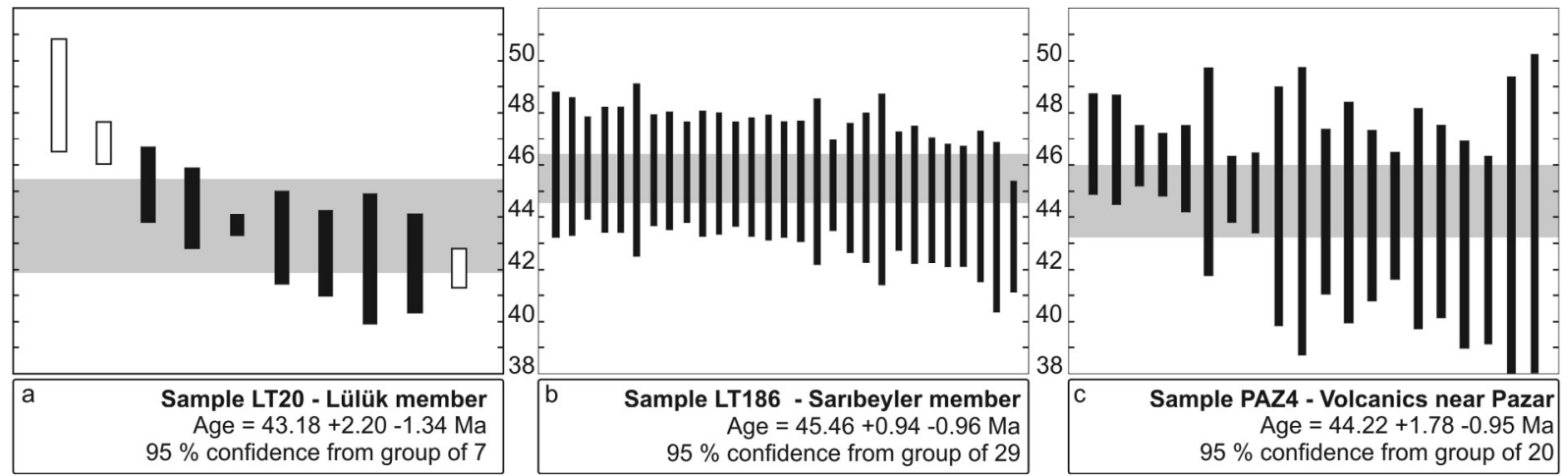

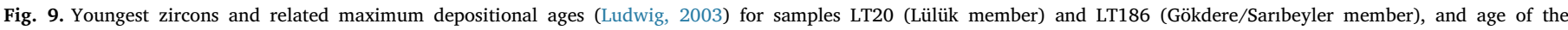

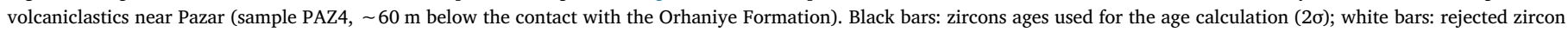
ages (2б). Grey shades: $95 \%$ confidence level for the calculated ages. Final ages include the systematic analytical error.

Sarıbeyler members.

The U-Pb zircon age distribution of the Dikmendede Formation (Fig. 8a) is made up of four major peaks: one major late Paleozoic Early Mesozoic 200-400 Ma peak, divided into two subpeaks at 200-260 Ma and 280-380 Ma that are also found in our sample from the closest rocks of the Pontide margin basement (Karakaya Complex; Fig. 8b), 550-670 Ma, 950-1080 Ma, and 1850-2200 Ma. The zircon age distribution of the Lülük member displays similar age peaks (Fig. 8c), but additionally displays a significant Cretaceous-Paleogene age population, yielding a maximum depositional age of $43.18+2.20-1.34(2 \sigma)$ Ma based on 7 zircon ages (Fig. 9a). The age distribution of the Gökdere/Sarıbeyler members is dominated by a single Paleogene peak (Fig. 8d) at 43-54 Ma, with a subordinate peak at 320-370 Ma. It yields a maximum depositional age of $45.46+0.94-0.96(2 \sigma)$ Ma based on 29 zircon ages (Fig. 9b).

Finally, zircons from a sample located at the top of the Paleogene volcaniclastic section in the Pazar area $(\sim 60 \mathrm{~m}$ below the Orhaniye Formation) yield a homogeneous age of $44.22+1.78-0.95(2 \sigma) \mathrm{Ma}$ based on 20 zircon ages (Fig. 9c). Note that we also tried to date the Orhaniye syenite by the same method, but our samples yielded no zircon.

\subsection{Paleomagnetic dating}

The initial intensities of $\mathrm{NRM}$ range from $3 \times 10^{-3} \mathrm{~A} / \mathrm{m}$ to $4 \times 10^{-6} \mathrm{~A} / \mathrm{m}$. The lacustrine limestone beds sampled in the
Gökdere and Sarıbeyler members display the weakest NRM intensity. Most samples are characterized by one component with high unblocking temperatures above $600{ }^{\circ} \mathrm{C}$ or two magnetization components (Fig. 10a-d). For samples with two-components magnetizations, a low stability component was removed between 100 and $300{ }^{\circ} \mathrm{C}$, and the Characteristic Remanent Magnetization (ChRM) directions were interpreted from the high-temperature component. Some specimens have strong low-temperature components and show erratic direction behaviors during the high temperature demagnetization process or have a very weak magnetization; thus no reliable results could be obtained. About one third of specimens yield erratic directions upon demagnetization and were discarded because of this noisy or ambiguous demagnetization behavior.

ChRM directions were determined with linear least squares fitting (Kirschvink, 1980) through the origin by using at least five continuous steps of demagnetization and with a maximum angular deviation smaller than $15^{\circ}$.

ChRM direction data are given in Supplementary Table 3 and plotted on stereographic diagrams (Fig. 10e). The ChRMs show both normal and reverse polarities, and yield a positive reversal test (McFadden and McElhinny, 1990) (classification C; $\gamma=13.9<\gamma c=16.1$ ). The distribution of the ChRMs satisfies the quality criteria of representing Paleo-Secular Variation (i.e., $\mathrm{A}_{95 \min }<\mathrm{A}_{95}<\mathrm{A}_{95 \max }$; Deenen et al., 2011). The tilt-corrected mean normal and reverse polarity directions after a fixed $45^{\circ}$ cutoff are $\mathrm{D}=349.1 \pm 10.3^{\circ}, \mathrm{I}=52.5 \pm 9.1^{\circ}\left(\mathrm{n}=25, \mathrm{~K}=12.2, \mathrm{~A}_{95}=8.6^{\circ}\right)$ 
A

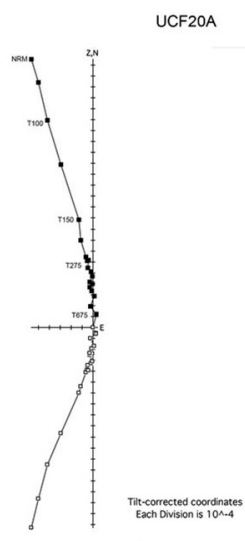

C

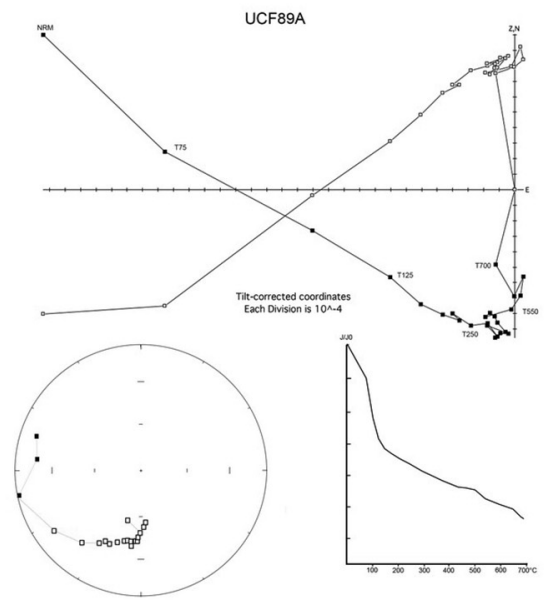

E

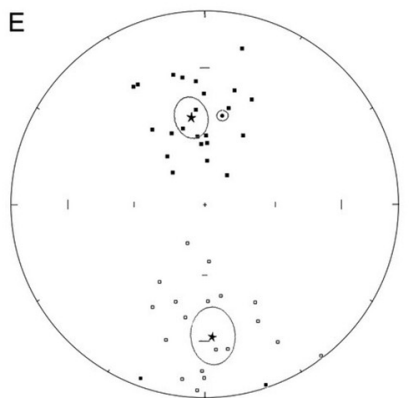

B
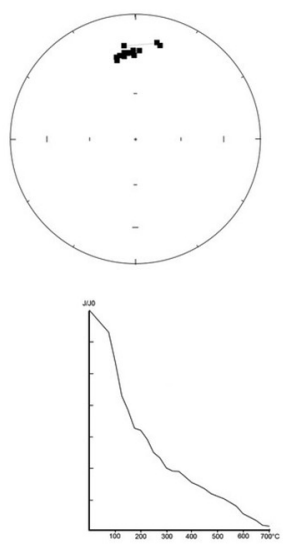

D

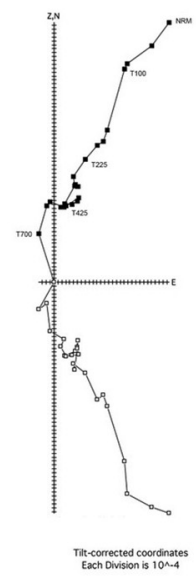

UCF45A
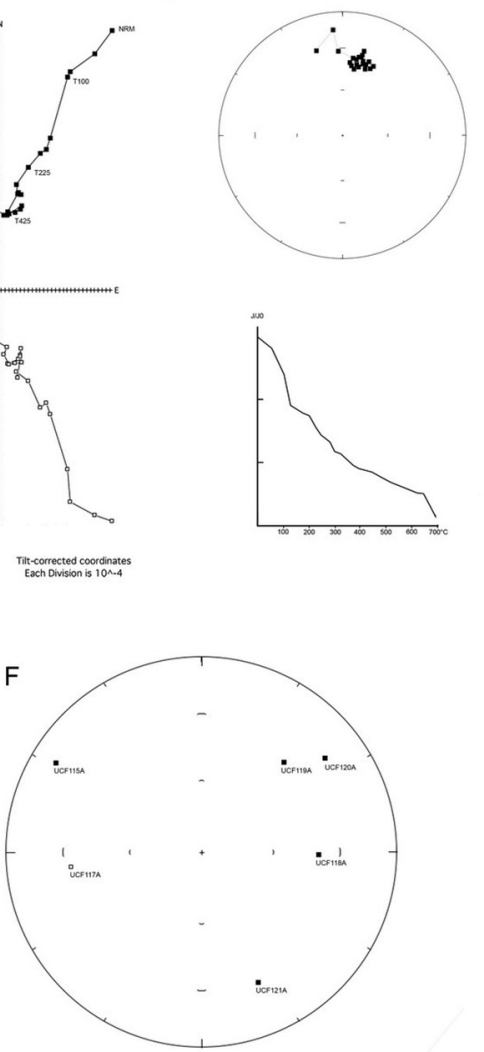

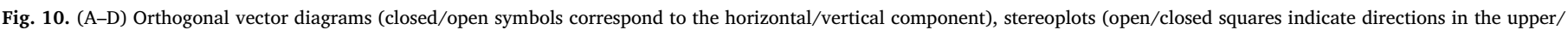

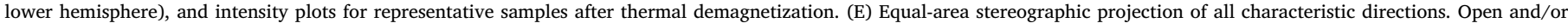

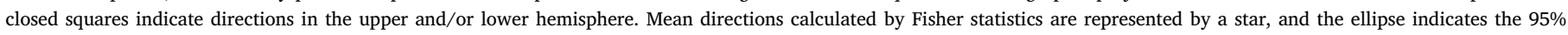

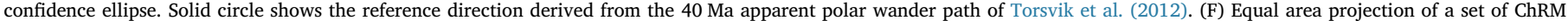
directions collected from different pebbles within a conglomerate stratum at the base of the Luiluik member.

and $\quad \mathrm{D}=175.6 \pm 9.2^{\circ}, \quad \mathrm{I}=-33.4 \pm 13.5^{\circ} \quad(\mathrm{n}=25, \quad \mathrm{~K}=11.9$, $\mathrm{A}_{95}=8.7^{\circ}$ )

A conglomerate test was performed on the ChRM directions of clasts sampled from a conglomerate bed at the base of the Lülük member. Six out of seven samples from the conglomerate bed yield reliable ChRMs (Fig. 10f). The magnetizations characteristic of the clasts are randomly distributed (Watson randomness criteria; Watson, 1956), implying ChRM acquisition is antecedent to the inclusion of the clasts in the conglomerate, which represents a positive conglomerate test.

The overall mean direction of the section is: $\mathrm{D}=351.9 \pm 6.2^{\circ}$, $\mathrm{I}=42 \pm 7.5^{\circ}\left(\mathrm{n}=50, \mathrm{~K}=13.3, \mathrm{~A}_{95}=5.7^{\circ}\right)$ after tilt adjustment, corresponding to the paleomagnetic pole at $72.7^{\circ} \mathrm{N}$ and $238.4^{\circ} \mathrm{E}$ $\left(A_{95}=7.2^{\circ}\right)$. We compared the overall mean direction of the section with the expected dipole paleomagnetic field directions $\left(\mathrm{D}=9.2^{\circ}\right.$, $\left.\mathrm{I}=51.6^{\circ}, \alpha_{95}=2.3^{\circ}\right)$ at the site location $\left(40.1^{\circ} \mathrm{N}, 32.7^{\circ} \mathrm{E}\right)$ derived from the reference paleomagnetic pole for Eurasia at $40 \mathrm{Ma}$ (Torsvik et al., 2012). The divergence between the observed declination from the expected declination $\left(17.3 \pm 6.9^{\circ}\right.$ of counterclockwise vertical axis rotation) requires either a local structural or regional tectonic explanation. Inclination values calculated for the section are lower than expected values; this sedimentary inclination error (sensu King, 1955) is commonly interpreted as reflecting depositional and post-deposi- 
tional processes that produce flattened directions (Verosub, 1977; Anson and Kodama, 1987).

The virtual geomagnetic pole (VGP) latitudes, calculated from the ChRM directions of each samples, are reported in Fig. 4. The magnetic polarity sequence established for the section includes two reverse (R1 and R2) and one normal (N1) polarity zones. Correlation to the Geomagnetic Polarity Time Scale of Gradstein et al. (2012) was guided by the maximum depositional ages provided by the zircon age distribution presented above $(\sim<4 \mathrm{Ma})$, and the late Lutetian age of the foraminiferal assemblage of the Orhaniye Formation ( $>41.2 \mathrm{Ma}$; Eraslan, 2006; Deveciler, 2014). Within this interval, the normal magnetozone N1 can only correlate to Chron C20n (43.43-42.3 Ma). According to this correlation, the magnetic polarity sequence of the section would represent Chrons C20r to C19r. This correlation would imply an age of ca. 44-42 Ma for the Uzunçarşıdere Formation, and ca. 44-43 Ma for the Lülük member and associated fossil fauna.

\subsection{Stable isotope data}

$\delta^{18} \mathrm{O}$ values from pedogenic carbonates of the Uzunçarşıdere Formation (Fig. 4) range from -5.6 to $-0.8 \%$ V-PDB (average $-3.6 \%$ ); $\delta^{13} \mathrm{C}$ values from pedogenic carbonates range from -7.4 to $-2.8 \%$ V-PDB (average $-5.5 \%$ ) and fall within the range of Late Eocene pedogenic $\delta^{13} \mathrm{C}$ values (e.g. Ekart et al., 1999; Caves et al., 2014; Licht et al., 2017).

$\delta^{18} \mathrm{O}$ values from lacustrine carbonates range from -8.6 to $-0.5 \%$ o V-PDB (average $-4.0 \%$ ); $\delta^{13} \mathrm{C}$ values from pedogenic carbonates range from -3.0 to $2.2 \%$ V-PDB (average $-1.1 \%$ ). These values are significantly different from marine carbonates isotopic values of the Orhaniye Formation in the study area $\left(\delta^{18} \mathrm{O}=-6.5 \%\right.$; $\left.\delta^{13} \mathrm{C}=3.5 \%\right)$. Two groups of lacustrine samples can be distinguished (Fig. 11). A first group of samples from the base of the Sarıbeyler member displays constant $\delta^{13} \mathrm{C}$ value around $-3 \%$ and a narrow range of $\delta^{18} \mathrm{O}$ values centred around $-3.5 \%$ (group 1 ). $\delta^{18} \mathrm{O}$ and $\delta^{13} \mathrm{C}$ values from other lacustrine samples (group 2) display a broader range of values with positive covariance $\left(r^{2}=0.4\right)$.

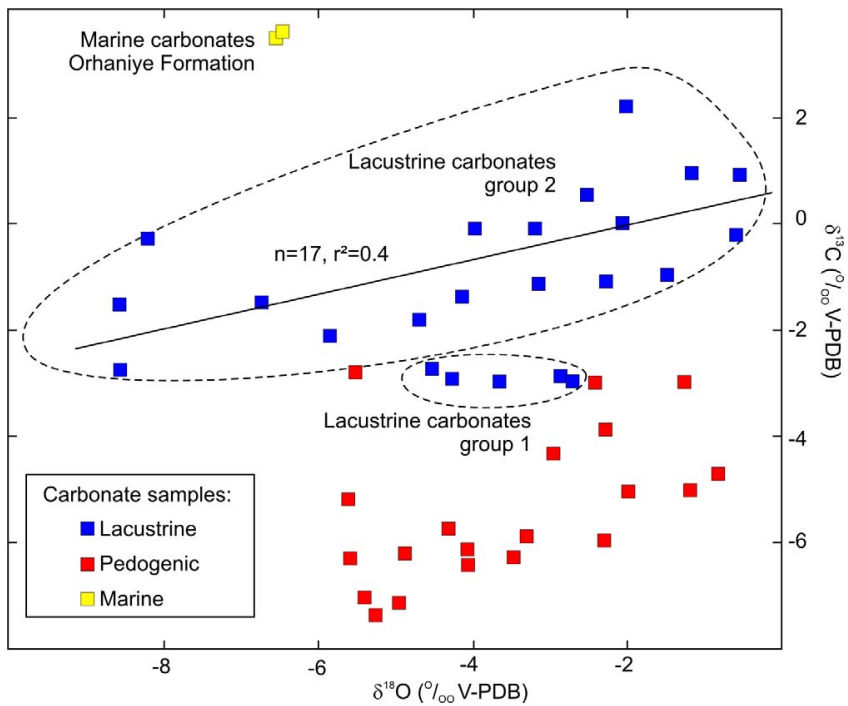

Fig. 11. Plot of $\delta^{18} \mathrm{O}$ versus $\delta^{13} \mathrm{C}$ values of all carbonate samples. Note that lacustrine carbonate samples can be divided into two groups: group 1 displays constant $\delta^{13} \mathrm{C}$ value around $-3 \%$ V-PDB and a narrow range of $\delta^{18} \mathrm{O}$ values; group 2 displays a wide spread of $\delta^{18} \mathrm{O}$ versus $\delta^{13} \mathrm{C}$ values following a general linear increasing trend $\left(r^{2}=0.4\right)$. Stratigraphic position of group 1 carbonates is indicated on Fig. 4 .

\section{Discussion}

\subsection{Evolution of the Orhaniye sub-basin from Maastrichtian to late Lutetian times}

Our new geochronological results for the Uzunçarşıdere Formation suggest rapid deposition ( $<2 \mathrm{Ma}$ for the complete fluvio-lacustrine sequence) in the late Lutetian, 44-42 Ma ago. Although we do not have a precise age constraint for the uppermost part of the Dikmendede Formation, Maastrichtian foraminifera from the uppermost marine levels of the latter unit (Sağular, 1986) coupled with our new data bearing on the age of the Uzunçarşıdere Formation suggest a $\sim 20 \mathrm{Ma}$ hiatus between the deposition of these rock formations.

Provenance data further emphasize the difference between these units. Ophiolitic clasts in Dikmendede flysch, grain-counts, and U-Pb zircon ages indicate that Dikmendede deposits are predominantly derived from a mixed denudation of Pontide basement rocks and ophiolitic material. This mixed provenance is supported by trace element analyses of Dikmendede sandstones (Özkan and Bozdag, 2009, 2011). Pontide basement rocks and ophiolitic material co-occur together in the NAOM that is well exposed to the southeast of the area of study, in the Ankara Accretionary Complex (Rojay, 2013); provenance from the Ankara Accretionary Complex is further supported by paleocurrent analyses in Dikmendede sandstones (Ocakoğlu, 1991; Ocakoglu and Çiner, 1995). By contrast, the Gökdere/Sarıbeyler members of the Uzunçarşıdere Formation are dominated by Paleogene volcanic clasts, with zircon ages very similar to those found to the north of the area of study, near Pazar. We interpret these observations as reflecting a prominent provenance from the early Galatean arc, located to the north and northwest of the area of study. The Lülük member displays intermediate age distribution and lithic content between the Dikmendede Formation and the Gökdere/Sarıbeyler members, with both characteristic zircon age peaks of the Maastrichtian flysch and Paleogene zircon ages. Our logs and paleocurrent measurements, similar to Ocakoğlu's (1991) earlier observations, indicate that the Lülük member represents the in-filling of a $\sim 100 \mathrm{~m}$ deep paleo-canyon incised into rocks of the Dikmendede Formation by a fluvial system sourced to the southeast, likely somewhere on the Ankara Accretionary Complex. Reworking of Dikmendede rocks explain the similarity between Dikmendede and Lülük age distributions; the minor amount of Paleogene zircons and volcanic clasts in Lülük member sandstones might reflect reworked volcanic pyroclastics and tuffs from the Galatean Arc deposited on the Ankara Accretionary Complex.

The incision of a $\sim 100 \mathrm{~m}$ deep paleo-canyon cannot be explained by a fall in sea-level alone, considering the known amplitude of eustatic variations of the Middle Eocene (Kominz et al., 2008) as well as evidence for a clear angular unconformity between the Dikmendede and Uzunçarşıdere Formations. Instead, it suggests that the incision of the Dikmendede Formation and subsequent in-filling by the Lülük member were in response to an uplift episode of the Ankara Accretionary Complex on the southeast flank of the Orhaniye sub-basin. Covariance between $\delta^{18} \mathrm{O}$ and $\delta^{13} \mathrm{C}$ values in most of the lacustrine carbonate samples of the Gökdere/Sarıbeyler members indicate hydrologically closed conditions following the in-filling of the Lülük paleocanyon (Talbot, 1990). Closed-basin conditions are corroborated by the numerous evaporitic, trona-bearing beds found in the lacustrine deposits on the other side of the Kazan syncline. The presence of a group of lacustrine carbonate samples showing no covariance and a narrow range of $\delta^{18} \mathrm{O}$ values -similar to those of pedogenic carbonatesafter deposition of the uppermost fluvial deposits suggests a transitional period with hydrologically open conditions before the final closure of the lake basin. This, together with evidence of local disconformities between the Uzunçarşıdere and overlying Orhaniye Formations, suggests that the Orhaniye sub-basin continued to be actively deformed after the initial uplift and incision of its southeast flank. The tectonostratigraphic evolution of the Orhaniye sub-basin can thus be synthe- 
a Model of Koçyiğit (1991)

Maastrichtian -

late Lutetian

- Locus of denudation
Maastrichtian - Paleocene deposits

Eocene deposits
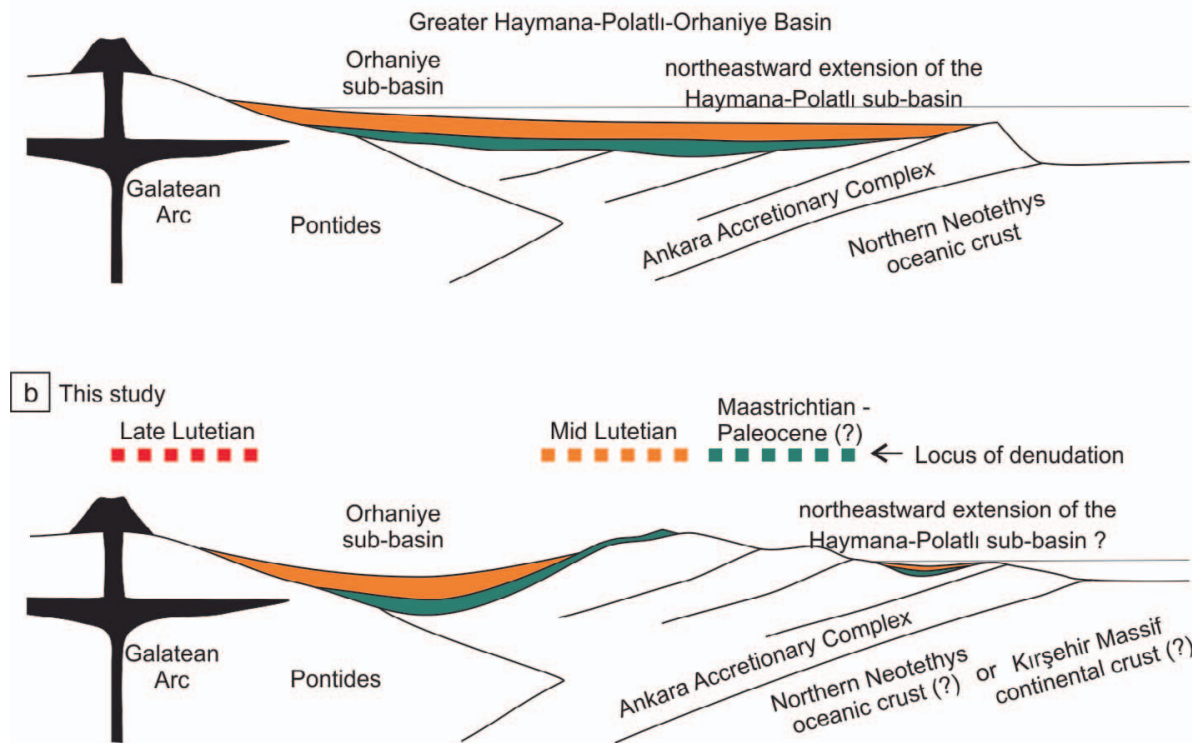

Fig. 12. (a) Model of Koçyiğit (1991) for the Great HPO Basin and (b) our proposed model for the Orhaniye sub-basin.

sized into four stages (Fig. 12):

(1) Until latest Maastrichtian- Early Paleocene (?) time, the Dikmendede Formation is deposited in response to emergence and uplift of the Ankara Accretionary Complex to the southeast of the Orhaniye quadrant.

(2) Incision of the Dikmendede Formation and deposition of the Lülük member result from the northwestward shift of uplift and denudation of the accretionary complex, reaching the flank of the Orhaniye sub-basin during the mid Lutetian.

(3) Uplift and deformation progresses further northwestward, resulting in the denudation of early Galatean arc rocks, in the closure of the Orhaniye lake system and the deposition of the Gökdere/Sarıbeyler members.

(4) Deformation and denudation temporarily ceases around 42-40 Ma, corresponding with a final marine incursion and the development of a shallow reefal platform, before over-filling the basin.

From 44 to $40 \mathrm{Ma}$, the quasi over-filled Orhaniye sub-basin has accumulated more than $400 \mathrm{~m}$ of sediment in its deepest parts while staying near-sea level. This is despite evidence for active compressional deformation on both the southeast and northwest sides of the basin. Although we have not observed growth strata structures due to limited exposure for the deeper part of the Orhaniye sub-basin, we suspect that the Uzunçarşıdere and Orhaniye Formations were deposited as infillings of the growing Kazan syncline.

\subsection{Model for the evolution of the IAES between the Kurşehir Massif and the Pontides}

The tectono-stratigraphic evolution of the Orhaniye sub-basin is much more complex than initially proposed by Koçyigit (1991). Considering the Orhaniye sub-basin as the peripheral part of a bigger HPO basin (Fig. 12a) would imply (1) sediment supply is sourced on the Pontide margin, to the northwest of the study area; (2) hydrologically open conditions. Our results show that the sub-basin was fed by the denudation of nearby rocks of the accretionary prism, located to the southeast, before being hydrologically closed and fed by the denudation of the Galatean arc on the Pontide margin. There is no evidence that the (sub-)basin was once connected to a hypothetical northeastward extension of the HPO basin. However, we cannot reject a potential extension of the HPO basin on the outer wedge of the Ankara Accretionary Complex that would have been completely eroded during later episodes of uplift of the prism (Fig. 12b).

Uplift and denudation of the accretionary prism during the Maastrichtian - Paleocene (?) and deposition of the Dikmendede flysch is consistent with a compressional accretionary-type forearc basin (sensu Noda, 2016), similar to a setting such as Sumatra and Java (Lüschen et al., 2011). The landward shift of denudation starting before $44 \mathrm{Ma}$, closure and possibly syndeformational development of the basin are rather uncommon in a forearc setting (Noda, 2016) but are typical of wedge-top piggy-back sub-basins in retroarc foreland basin systems (De Celles and Giles, 1996; Lawton et al., 1999). In this sense, the evolution of the Orhaniye sub-basin mirrors the deformation history of the Çankırı and Kırıkkale Basins between the Kırşehir Massif and the Pontides, both of which were deformed and structurally partitioned since the Paleocene (Rice et al., 2006; Kaymakçi et al., 2009; Nairn et al., 2012). This interpretation implies suturing of the IAES between the Kurşehir Massif and the Pontides sometime between the early Paleocene and $44 \mathrm{Ma}$. This entire period is marked by quasi-continuous volcanic activity of the Galatean arc, Paleogene rocks of which are today mostly covered by Miocene volcanic rocks but are yet documented in the 54-43 Ma zircon ages found in the Uzunçarşıdere Formation. The last continuous seaway development between the Pontides and the Kırşehir Massif at 42-40 Ma -documented by the Orhaniye Formation in the Orhaniye (sub-)basin and by the Kocaçay Formation in the Çankırı Basin- occurred after oceanic basin closure along the IAES, with a sea incursion along the growing Kazan syncline before its over-filling.

Our chronology for the Orhaniye Basin thus supports a two-step scenario for the closure of the IAES zone and the assemblage of the central Anatolian landmass (Rice et al., 2006), with the onset of collision tectonics between the Kırşehir Massif and the Pontide margin sometime between the early Paleocene and $44 \mathrm{Ma}$, and final sea retreat and seaway closure along the collision zone in the earliest Bartonian after the last marine incursion into the foreland basin. 


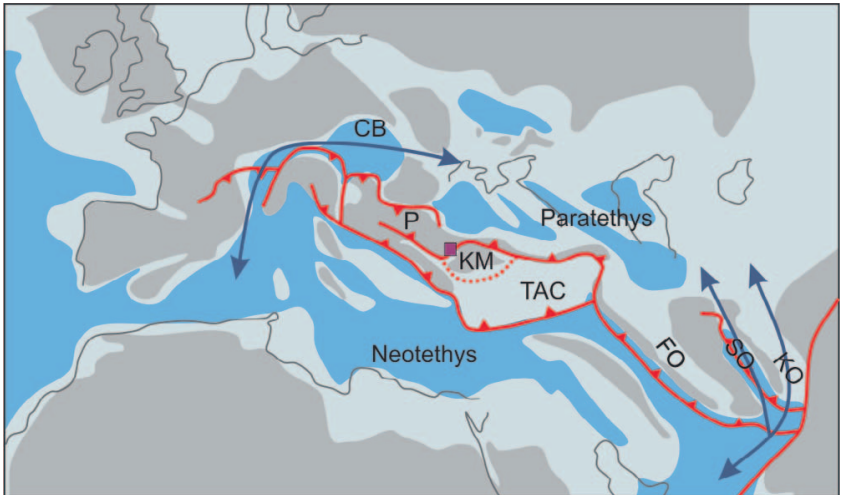

Fig. 13. Paleogeography of the late Middle Eocene after Barrier and Vrielynck (2008), with emerged areas (grey), shallow (light blue) and deep (dark blue) marine domain, major convergence zones and faults (red lines). Purple square: Orhaniye (sub-)basin; blue arrows: persistent seaways connecting Paratethys and Neotethys oceans, likely causes for Anatolian faunal endemism. P: Pontides; KM: Kırşehir Massif; TAC: Tauride-Anatolide Continent; CB: Carpathian Basin; FO: Fannuj Ocean; SO: Sistan Ocean; KO: Katawaz Ocean. (For interpretation of the references to colour in this figure legend, the reader is referred to the web version of this article.)

\subsection{Implications for the Eocene Anatolian fauna and ecosystems}

Pedogenic carbonate growth in the fluvial/coastal depositional environment of the Uzunçarşıdere Formation, a wide range of pedogenic $\delta^{18}$ O values, as well as high smectite content (Ocakoğlu, 1998) are common indicators of marked seasonally dry conditions (Breecker et al., 2009; Licht et al., 2014a). Low $\delta^{18} \mathrm{O}$ values in the marine carbonates of the Orhaniye Formation $(\sim-6 \%)$ are at the lowermost margin of the range of values found in modern marine carbonates and suggest shallow marine conditions with high sea surface temperatures and significant freshwater input, such as seen today along the Cortez Sea shores (Rowell et al., 2005). Episodes of significant meteoric input can also explain the low $\delta^{18} \mathrm{O}$ values (up to $-8.5 \%$ V-PDB) in some lacustrine carbonate samples from the Uzunçarşıdere Formation. These low carbonate $\delta^{18} \mathrm{O}$ values correspond to meteoric $\delta^{18} \mathrm{O}$ values around -5 to $-7 \%$ or lower (values calculated with the calcite-water fractionation relationship of Kim and O'Neil, 1997, using temperature of $25-35^{\circ} \mathrm{C}$ ). After correction by $\sim 1 \%$ due to different seawater isotopic composition during the Eocene (Tindall et al., 2010), these meteoric values are very similar to calculated meteoric values from Oligocene deposits of southern Anatolia (Lüdecke et al., 2013) as well as to modern meteoric values near sea level along the Turkish Mediterranean coast (Schemmel et al., 2013). These low values suggest that the Gökdere/Sarıbeyler closed-lake system was mainly fed by freshwater and did not form in a brackish lagoonal setting. This is supported by the presence of trona evaporites, which only form in closed freshwater lakes with volcanic lithologies in the drainage basin (Earman et al., 2005). These observations thus suggest that the Uzunçarşıdere fauna lived along the shore of a freshwater lacustrine ecosystem developed under wet climatic conditions, yet with a wellmarked dry season and significant evaporation. They support the expansion of monsoonal ecosystems along the Eurasian Tethyan shorelines during the Eocene, in response to greenhouse conditions (Huber and Goldner, 2012; Licht et al., 2014b).

The 44-43 Ma (late Lutetian) age for the Uzunçarşıdere mammal fauna indicates that terrestrial vertebrates in northern Anatolia evolved largely in isolation from those on adjacent parts of Laurasia for at least $15 \mathrm{Ma}$, from the Late Paleocene to the late Middle Eocene. Moreover, despite collision and suturing of the Pontide and Tauride-Anatolide landmasses, the Eocene Uzunçarşıdere mammal fauna also differs appreciably from those currently known from Africa (Şen, 2013). This indicates that (1) the TAC is a poor candidate to have served as a stepping stone between the African and Eurasian landmasses, effec- tively eliminating this route as a potential pathway for Transtethyan mammal dispersal during the Eocene (Tabuce and Marivaux, 2005; Chaimanee et al., 2012; Şen, 2013; Beard, 2016); (2) seaways wide enough to block the dispersal of continental mammals from Europe and Asia to Anatolia must have persisted at least until the late Middle Eocene, connecting the Paratethys to the north and the Neotethys to the south. These marine obstacles to mammalian dispersal across the southern margin of Laurasia during the Eocene likely included the Sistan, Fannuj, and Katawaz Oceans in Iran and Pakistan to the east (McCall, 2002) and the Carpathian Basin seaway to the west (Barrier and Vrielynck, 2008; Fig. 13).

\section{Conclusion}

Our approach combining sedimentology, magnetostratigraphy, petrography, and U-Pb geochronology has shown that the Orhaniye (sub-) Basin initially developed in a forearc setting on the Ankara Accretionary Complex during the Maastrichtian. The transition to a retroarc foreland basin setting occurred sometime between the Early Paleocene and $44 \mathrm{Ma}$. This chronology resembles those which have been reported for two other basins occurring along the IAES between the Kırşehir Massif and the Pontides. It supports a two-step scenario for the assemblage of the central Anatolian landmass, with incipient collision during the Paleocene - early Eocene and final seaway closure in the earliest Bartonian after the last marine incursion into the foreland basin. Our results provide no evidence for a greater HPO Basin; the Orhaniye (sub-)Basin evolved independently from the Haymana-Polatlı (sub-)Basin since at least $44 \mathrm{Ma}$, and potentially earlier.

Our new age constraints for the Uzunçarşıdere fauna indicate the persistence of Paleogene Anatolian endemism until at least $44 \mathrm{Ma}$, suggesting that northern Anatolia lacked direct terrestrial connections with nearby parts of Laurasia throughout much of the Early Paleogene. Despite the advanced stage of collision, the Pontide-TAC assemblage remained isolated from both Asia and Europe until at least the late Middle Eocene, and potentially later (cf. de Bruijn et al., 2003).

\section{Acknowledgments}

This work has been supported by the INSU-2011 CT4 Interrvie, the Action Transversale Muséum (2012), the National Geographic CRE GRANT \#9215-12, and U.S. National Science Foundation grant EAR1543684. A.L. was also funded by the E.U. horizon-2020 project 656731 'ECCAMETT'. We thank N. Mclean, A. Möller, M. Pecha, G. Simpson, I. Nurmaya, C. White, J. Quade, J. Fiebig, S. Hofmann, U. Treffert, D. Bajnai, J. Holt, and M. Christoffersen for prolific discussions and assistance in the lab. We also thank two anonymous reviewers for their useful and encouraging comments.

\section{References}

Advokaat, E.L., van Hinsbergen, D.J., Kaymakc1, N., Vissers, R.L., Hendriks, B.W., 2014. Late Cretaceous extension and Palaeogene rotation-related contraction in Central Anatolia recorded in the Ayhan-Büyükkışla basin. Int. Geol. Rev. 56 (15), 1813-1836.

Akiman, O., Erler, A., Göncüoğlu, M.C., Güleç, N., Geven, A., Türeli, T.K., Kadioğlu, Y.K., 1993. Geochemical characteristics of granitoids along the western margin of the Central Anatolian Crystalline Complex and their tectonic implications. Geol. J. 28 (3-4), 371-382.

Anson, G.L., Kodama, K.P., 1987. Compaction-induced inclination shallowing of the postdepositional remanent magnetization in a synthetic sediment. Geophys. J. Int. 88, 673-692.

Altıner, D., Koçyiğit, A., Farinacci, A., Nicosia, U., Conti, M.A., 1991. Jurassic-lower Cretaceous stratigraphy and paleogeographic evolution of the southern part of northwestern Anatolia (Turkey). Geol. Romana 27, 13-80.

Beard, K.C., 2016. Out of Asia: anthropoid origins and the colonization of Africa. Annu. 
Rev. Anthropol. 45, 199-213.

Barrier, E., Vrielynck, B., 2008. Palaeotectonic Maps of the Middle East. Commission for the Geological Map of the World, Paris.

Breecker, D.O., Sharp, Z.D., McFadden, L.D., 2009. Seasonal bias in the formation and stable isotopic composition of pedogenic carbonate in modern soils from central New Mexico, USA. Geol. Soc. Am. Bull. 121 (3-4), 630-640.

Botev, Z.I., Grotowski, J.F., Kroese, D.P., 2010. Kernel density estimation via diffusion. Ann. Stat. 38, 2916-2957.

Boztuğ, D., Jonckheere, R.C., 2007. Apatite fission track data from central Anatolian granitoids (Turkey): constraints on Neo-Tethyan closure. Tectonics 26 (3).

Caves, J.K., Sjostrom, D.J., Mix, H.T., Winnick, M.J., Chamberlain, C.P., 2014. Aridification of Central Asia and uplift of the Altai and Hangay Mountains, Mongolia: stable isotope evidence. Am. J. Sci. 314 (8), 1171-1201.

Chaimanee, Y., Chavasseau, O., Beard, K.C., Kyaw, A.A., Soe, A.N., Sein, C., Lazzari, V., Marivaux, L., Marandat, B., Swe, M., Rugbumrung, M., 2012. Late Middle Eocene primate from Myanmar and the initial anthropoid colonization of Africa. Proc. Natl. Acad. Sci. 109 (26), 10293-10297.

Cemen, I., Göncüoglu, M.C., Dirik, K., 1999. Structural evolution of the Tuzgölü basin in Central Anatolia, Turkey. J. Geol. 107 (6), 693-706.

Collinson, J.D., Thompson, D.B., 1989. Sedimentary Structures. Unwin Hyman, London.

Ciner, A., Deynoux, M., Ricou, S., Kosun, E., 1996. Cyclicity in the Middle Eocene Cayraz Carbonate formation, Haymana Basin, Central Anatolia, Turkey. Paleogeography, Paleoclimatology, Paleoecology 121, 313-329.

de Bruijn, H., Ünay, E., Saraç, G., Yilmaz, A., 2003. A rodent assemblage from the Eo/ Oligocene boundary interval near Süngülü, lesser Caucasus, Turkey. Coloquios de Paleontología 1, 47-76.

Duru, M., Aksay, A., 2002. Türkiye Jeoloji Haritalary N ${ }^{\circ} 42$, Bolu H29 Paftasi. (Geological map of Kazan Quadrant, central Anatolia). Jeoloji Etütleri Dairesi, Ankara.

De Celles, P.G., Giles, K.A., 1996. Foreland basin systems. Basin Res. 8 (2), 105-123.

Deenen, M.H., Langereis, C.G., van Hinsbergen, D.J., Biggin, A.J., 2011. Geomagnetic secular variation and the statistics of palaeomagnetic directions. Geophys. J. Int. 186 (2), 509-520.

Deveciler, A., 2014. Description of larger benthic Foraminifera species from the Bartonian of Yakacik-Memlik Region (N Ankara, Central Turkey). Bull. Earth Sci. Appl. Res. Centre Hacettepe Univ. 35 (2), 137-150.

Dickinson, W.R., 1985. Interpreting provenance relations from detrital modes of sandstones. In: Zuma, G.G. (Ed.), Provenance of Arenites. Reidel, Dordrecht, pp. 333-361.

Dinçer, F., 2016. Eocene benthic foraminiferal assemblages from Central Anatolia (Turkey): biostratigraphy, stable isotope data, paleoenvironmental and paleontological interpretations. J. Afr. Earth Sc. 114, 143-157.

Earman, S., Phillips, F.M., McPherson, B.J., 2005. The role of "excess" $\mathrm{CO}_{2}$ in the formation of trona deposits. Appl. Geochem. 20 (12), 2217-2232.

Ekart, D.D., Cerling, T.E., Montanez, I.P., Tabor, N.J., 1999. A 400 million year carbon isotope record of pedogenic carbonate: implications for paleoatmospheric carbon dioxide. Am. J. Sci. 299 (10), 805-827.

Eraslan, A., 2006. Eocene Stratigraphy and benthic foraminifera of Baglum-Kazan (NW Ankara) Region. Master Thesis, ÇUKUROVA ÜNIVERSITESI, Turkey.

Erdal, O., Antoine, P.O., Sen, S., 2016. New material of Palaeoamasia kansui (Embrithopoda, Mammalia) from the Eocene of Turkey and a phylogenetic analysis of Embrithopoda at the species level. Palaeontology 59 (5), 631-655.

Fisher, R., 1953. Dispersion on a sphere. Proc. Roy. Soc. London 217, 295-305.

Gile, L.H., Peterson, F.F., Grossman, R.B., 1966. Morphological and genetic sequences of carbonate accumulation in desert soils. Soil Sci. 101, 347-360.

Gökten, E., Kazanci, N., Acar, S., 1988. Stratigraphy and tectonics of the Upper Cretaceous-Pliocene series northwest of Ankara (Between Baglum and Kazan). Maden Tetkik ve Arama Dergisi 108, 69-81.

Görür, N., 1988. Timing of opening of the Black Sea basin. Tectonophysics 147 (3), $247-262$.

Görür, N., Oktay, F., Seymen, I., Sengör, A., 1984. Palaeotectonic evolution of the Tuzgölü basin complex, Central Turkey: sedimentary record of a Neo-Tethyan closure. Geol. Soc., London, Spec. Publ. 17, 467-482.

Görür, N., Tüysüz, O., Celal Sengo, A., 1998. Tectonic evolution of the central Anatolian basins. Int. Geol. Rev. 40, 831-850.

Gradstein, F.M., Ogg, G., Schmitz, M., 2012. The Geologic Time Scale 2012 2-Volume Set. Elsevier.

Gülyüz, E., Kaymakci, N., Meijers, M.J., Van Hinsbergen, D.J., Lefebvre, C., Vissers, R.L., et al., 2013. Late Eocene evolution of the Çiçekdağı Basin (central Turkey): Synsedimentary compression during microcontinent-continent collision in central Anatolia. Tectonophysics 602, 286-299.

Gürer, O., Aldanmaz, E., 2002. Origin of the Upper Cretaceous-Tertiary sedimentary basins within the Tauride-Anatolide platform in Turkey. Geol. Mag. 139, 191-197.

Huber, M., Goldner, A., 2012. Eocene monsoons. J. Asian Earth Sci. 44, 3-23.

Johnson, C.L., Constable, C.G., Tauxe, L., Barendregt, R., Brown, L.L., Coe, R.S., et al. 2008. Recent investigations of the $0-5$ Ma geomagnetic field recorded by lava flows. Geochem. Geophys. Geosyst. 9 (4).

Jones, C.H., 2002. User-driven integrated software lives: "Paleomag" paleomagnetics analysis on the Macintosh. Comput. Geosci. 28, 1145-1151.

Kappelman, J., Maas, M.C., Sen, S., Alpagut, B., Fortelius, M., Lunkka, J.-P., 1996. A new early Tertiary mammalian fauna from Turkey and its paleobiogeographic significance. J. Vertebr. Paleontol. 16, 592-595.

Kaymakç1, N., White, S.H., Van Dijk, P.M., 2000. Palaeostress inversion in a multiphase deformed area: kinematic and structural evolution of the Çankırı Basin (Central Turkey), Part 1 - Northern Area. Geol. Soc., London, Spec. Publ. 173 (1), 295-323.

Kaymakçı, N., Özçelik, Y., White, S.H., Van Dijk, P.M., 2009. Tectono-stratigraphy of the Çankırı Basin: late Cretaceous to early Miocene evolution of the Neotethyan suture zone in Turkey. Geol. Soc., London, Spec. Publ. 311 (1), 67-106.

Kazanc1, N., Gokten, E., 1986. Sedimentary characteristics of terrestrial Paleocene deposits in Northern Ankara region, Turkey. Commun. Fac. Sci. Univ. Ank. Serie C 4 153-163.

Kazancı, N., Kappelman, J., Varol, B., Sen, S., Karadenizli, L., Maas, M., Gül, A.A., Alçiçek, M., Copeland, P., 2001. New age determinations for the Palaeogene Continental Succession North of Ankara, central Anatolia, Turkey. Fourth International Turkish Geology Symposium abstracts, Adana Turkey.

Kim, S., O'Neil, J., 1997. Equilibrium and nonequilibrium oxygen isotope effects in synthetic carbonates. Geochim. Cosmochim. Acta 61, 3461-3475.

King, R.F., 1955. The remanent magnetism of artificially deposited sediments. Geophys. J. Int. $7,115-134$

Kirschvink, J.L., 1980. The least-squares line and plane and the analysis of palaeomagnetic data. Geophys. J. Int. 62, 699-718.

Koçyiğit, A., Özkan, S., Rojay, B., 1988. Examples from the fore arc basin remnant at the active margin of Northern Neo-Tethys: emplacement age of the Anatolian Nappe. METU J. Pure Appl. Sci. 21 (1-3), 183-210.

Koçyiğit, A., 1991. An example of an accretionary forearc basin from northern Central Anatolia and its implications for the history of subduction of Neo-Tethys in Turkey. Geol. Soc. Am. Bull. 103, 22-36.

Kominz, M.A., Browning, J.V., Miller, K.G., Sugarman, P.J., Mizintseva, S., Scotese, C.R., 2008. Late Cretaceous to Miocene sea-level estimates from the New Jersey and Delaware coastal plain coreholes: an error analysis. Basin Res. 20 (2), 211-226.

Koymans, M.R., Langereis, C.G., Pastor-Galán, D., van Hinsbergen, D.J., 2016. Paleomagnetism.org: an online multi-platform open source environment for paleomagnetic data analysis.

Lawton, T.F., Roca, E., Guimerà, J., 1999. Kinematic-stratigraphic evolution of a growth syncline and its implications for tectonic development of the proximal foreland basin, southeastern Ebro basin, Catalunya, Spain. Geol. Soc. Am. Bull. 111 (3), 412-431.

Lefebvre, C., Meijers, M.J., Kaymakci, N., Peynircioğlu, A., Langereis, C.G., Van Hinsbergen, D.J., 2013. Reconstructing the geometry of central Anatolia during the late Cretaceous: large-scale Cenozoic rotations and deformation between the Pontides and Taurides. Earth Planet. Sci. Lett. 366, 83-98.

Licht, A., Cojan, I., Caner, L., Soe, A.N., Jaeger, J.J., France-Lanord, C., 2014a. Role of permeability barriers in alluvial hydromorphic palaeosols: the Eocene Pondaung Formation, Myanmar. Sedimentology 61 (2), 362-382.

Licht, A., Van Cappelle, M., Abels, H.A., Ladant, J.B., Trabucho-Alexandre, J., FranceLanord, C., Donnadieu, Y., Vandenberghe, J., Rigaudier, T., Lécuyer, C., Terry Jr., D. 2014b. Asian monsoons in a late Eocene greenhouse world. Nature 513, 501-506.

Licht, A., Dupont-Nivet, G., Pullen, A., Kapp, P., Abels, H.A., Lai, Z., Guo, Z., Abell, J., Giesler, D., 2016. Resilience of the Asian atmospheric circulation shown by Paleogene dust provenance. Nat. Commun. 7.

Licht, A., Quade, J., Kowler, A., De Los Santos, M., Hudson, A., Schauer, A., Huntington, K., Copeland, P., Lawton, T., 2017. Impact of the North American monsoon on isotope paleoaltimeters: implications for the paleoaltimetry of the American Southwest. Am. J. Sci. $317,1-33$.

Lüdecke, T., Mikes, T., Rojay, F.B., Cosca, M.A., Mulch, A., 2013. Stable isotope-based reconstruction of Oligo-Miocene paleoenvironment and paleohydrology of Central Anatolian lake basins (Turkey). Turk. J. Earth Sci. 22 (5), 793-819.

Ludwig, K.R., 2003. User's manual for Isoplot 3.00: a geochronological toolkit for Microsoft Excel (No. 4). Kenneth R. Ludwig.

Lüschen, E., Müller, C., Kopp, H., Engels, M., Lutz, R., Planert, L., Shulgin, A. Djajadihardja, Y.S., 2011. Structure, evolution and tectonic activity of the eastern Sunda forearc, Indonesia, from marine seismic investigations. Tectonophysics 508 (1), 6-21.

Maas, M.C., Thewissen, J.G.M., Kappelman, J., 1998. Hypsamasia seni (Mammalia: Embrithopoda) and other mammals from the Eocene Kartal Formation of Turkey. Bull. Carnegie Mus. Nat. Hist. 34, 286-297.

Maas, M.C., Thewissen, J.G.M., Sen, S., Kazanci, N., Kappelman, J., 2001. Enigmatic new ungulates from the early middle Eocene of central Anatolia, Turkey. J. Vertebr. Paleontol. 21, 578-590.

McCall, G.J.H., 2002. A summary of the geology of the Iranian Makran. Geol. Soc., London, Spec. Publ. 195 (1), 147-204.

McFadden, P.L., McElhinny, M.W., 1990. Classification of the reversal test in palaeomagnetism. Geophys. J. Int. 103, 725-729.

Meijers, M.J., Kaymakçı, N., Van Hinsbergen, D.J., Langereis, C.G., Stephenson, R.A., Hippolyte, J.C., 2010. Late Cretaceous to Paleocene oroclinal bending in the central Pontides (Turkey). Tectonics 29 (4).

Menant, A., Jolivet, L., Vrielynck, B., 2016. Kinematic reconstructions and magmatic evolution illuminating crustal and mantle dynamics of the eastern Mediterranean region since the late Cretaceous. Tectonophysics 675, 103-140.

Métais, G., Gheerbrant, E., Sen, S., 2012. Re-interpretation of the genus Parabunodon (Ypresian, Turkey): implications for the evolution and distribution of pleuraspidotheriid mammals. Palaeobiodiversity Palaeoenvironments 92, 477-486.

Métais, G., Erdal, O., Erturaç, K., Beard, K.C., 2017. Tarsal morphology of the pleuraspidotheriid mammal Hilalia from the middle Eocene of Turkey. Acta Palaeontol. Pol. 62 (1), 173-179.

Nairn, S., Robertson, A., Ünlügenç, U., Tasli, K., Inan, N., 2012. Tectonostratigraphic evolution of the Upper Cretaceous - Cenozoic central Anatolian basins: an integrated study of diachronous ocean basin closure and continental collision. Geol. Soc., London, Spec. Publ. 372, 343-384.

Najman, Y., 2006. The detrital record of orogenesis: a review of approaches and techniques used in the Himalayan sedimentary basins. Earth Sci. Rev. 74, 1-72.

Nie, J., Peng, W., Moller, A., Song, Y., Stockli, D., Stevens, T., Horton, B., Liu, S., Bird, A., Oalmann, J., Gong, H., Fang, X., 2014. Provenance of the upper Miocene-Pliocene Red Clay deposits of the Chinese loess plateau. Earth Planet. Sci. Lett. 2014 (407), 
$35-47$.

Noda, A., 2016. Forearc basins: types, geometries, and relationships to subduction zone dynamics. Geol. Soc. Am. Bull B31345-1.

Ocakoğlu, F., 1991. Stratigraphie et sédimentologie des dépôts continentaux d'age Paleocene-Eocene inferieure de la region d'Orhaniye-Güvenç (NNO d'Ankara). Master Thesis. Universite d'Hacettepe, Ankara, Institut des Sciences Fondamentales, 149p (in French).

Ocakoğlu, F., Çiner, A., 1995. Sedimentary evolution of the Orhaniye-Guvenc (NW Ankara) continental deposits during Paleocene-Early Eocene. Geol. Bull. Turkey 38, 53-66.

Ocakoğlu, F., 1998. Clay stratigraphy of the Upper Cretaceous-Eocene sediments in the Orhaniye Region (Northern Ankara): some implications to paleoenvironmental and paleoclimatic conditions. Geol. Bull. Turkey A1, 31-39.

Okay, A.I., Tüysüz, O., 1999. Tethyan sutures of northern Turkey. Geol. Soc., London, Spec. Publ. 156 (1), 475-515.

Özkan, A., Bozdag, A., 2009. The petrography and provenance of Dikmendede Formation (Maastrichtian) sandstones in the Orhaniye (Kazan-Ankara) area. J. Fac. Eng. Arch. Selcuk Univ. 24, 18-32.

Özkan, A., Bozdag, A., 2011. Geochemistry and provenance of Maastrichtian clastic rocks in the Dikmendede formation of Orhaniye in Kazan-Ankara-Turkey region. Acta Geol. Sin. 85 (5), 1067-1083.

Pourteau, A., Candan, O., Oberhänsli, R., 2010. High-pressure metasediments in central Turkey: constraints on the Neotethyan closure history. Tectonics 29 (5).

Rice, S., Robertson, A., Ustaömer, T., 2006. Late Cretaceous-Early Cenozoic tectonic evolution of the Eurasian active margin in the Central and Eastern Pontides, northern Turkey. Geol. Soc., London, Spec. Publ. 260, 413-445.

Robertson, A., Parlak, O., Ustaomer, T., 2009. Melange genesis and ophiolite emplacement related to subduction of the northern margin of the Tauride-Anatolide continent, central and western Turkey. Geol. Soc., London, Spec. Publ. 311, 9-66.

Robertson, A., Parlak, O., Ustaomer, T., 2013. Late Palaeozoic - early Cenozoic tectonic development of southern Turkey and the easternmost Mediterranean region: evidence from the inter-relations of continental and oceanic units. Geol. Soc., London, Spec. Publ. 372, 9-48.

Rojay, B., 2013. Tectonic evolution of the Cretaceous Ankara Ophiolitic Mélange during the Late Cretaceous to pre-Miocene interval in Central Anatolia, Turkey. J. Geodyn. 65, 66-81.

Rowell, K., Flessa, K.W., Dettman, D.L., Román, M., 2005. The importance of Colorado River flow to nursery habitats of the Gulf corvina (Cynoscion othonopterus). Can. J. Fish. Aquat. Sci. 62 (12), 2874-2885.

Sağular, E.K., 1986. Cretaceous nannoplankton biostratigraphy of the Orhaniye area (NW Ankara). Master Thesis Ankara University, Graduate School of Natural and Applied Sciences 70p.

Sanders, W.J., Nemec, W., Aldinucci, M., Janbu, N.E., Ghinassi, M., 2014. Latest evidence of Palaeoamasia (Mammalia, Embrithopoda) in Turkish Anatolia. J. Vertebr. Paleontol. 34, 1155-1164.
Schemmel, F., Mikes, T., Rojay, B., Mulch, A., 2013. The impact of topography on isotopes in precipitation across the Central Anatolian Plateau (Turkey). Am. J. Sci. 313 (2), 61-80.

Şen, S., 2013. Dispersal of African mammals in Eurasia during the Cenozoic: ways and whys. Geobios 46 (1), 159-172.

Sengör, A.M.C., Yılmaz, Y., 1981. Late Cretaceous-Early Eocene tectonic development of the Tethyan suture zone in the Erzincan area, Eastern Pontides, Turkey. Tectonophysics 75, 181-241.

Şengör, A.M.C., Yılmaz, Y., Sungurlu, O., 1984. Tectonics of the Mediterranean Cimmerides: nature and evolution of the western termination of Palaeo-Tethys. Geol. Soc., London, Spec. Publ. 17 (1), 77-112.

Tabuce, R., Marivaux, L., 2005. Mammalian interchanges between Africa and Eurasia: an analysis of temporal constraints on plausible anthropoid dispersals during the Paleogene. Anthropol. Sci. 113, 27-32.

Talbot, M.R., 1990. A review of the palaeohydrological interpretation of carbon and oxygen isotopic ratios in primary lacustrine carbonates. Chem. Geol. 80 (4), 261-279.

Tindall, J., Flecker, R., Valdes, P., Schmidt, D., Markwick, P., Harris, J., 2010. Modelling the oxygen isotope distribution of ancient seawater using a coupled ocean-atmosphere GCM: implications for reconstructing early Eocene climate. Earth Planet. Sci. Lett. 292, 265-273.

Tokay, M., Lünel, A., Kocyigi, A., 1988. Geology and petrology of the Gökdere stock of the Orhaniye syenite. METU J. Pure Appl. Sci. 21 (1-3), 1-37.

Torsvik, T.H., Van der Voo, R., Preeden, U., Mac Niocaill, C., Steinberger, B., Doubrovine, P.V., van Hinsbergen, D.J., Domeier, M., Gaina, C., Tohver, E., Meert, J.G., 2012. Phanerozoic polar wander, palaeogeography and dynamics. Earth Sci. Rev. 114 (3), 325-368.

Ünalan, G., Yüksel, V., Tekeli, T., Gönenç, O., Seyirt, Z., Hüseyin, S., 1976. The stratigraphy and palaeogeographical evolution of the Upper Cretaceous-Lower Tertiary sediments in the Haymana-Polatlı region (SW of Ankara). Türkiye Jeoloji Kurumu Bülteni 19, 159-176.

van Hinsbergen, D.J., Kaymakc1, N., Spakman, W., Torsvik, T.H., 2010. Reconciling the geological history of western Turkey with plate circuits and mantle tomography. Earth Planet. Sci. Lett. 297 (3), 674-686.

Van Hinsbergen, D.J., Maffione, M., Plunder, A., Kaymakcı, N., Ganerød, M., Hendriks, B.W., Corfu, F., Gürer, D., Gelder, G.I., Peters, K., McPhee, P.J., 2016. Tectonic evolution and paleogeography of the Kırşehir Block and the Central Anatolian Ophiolites, Turkey. Tectonics 35 (4), 983-1014.

Verosub, K.L., 1977. Depositional and postdepositional processes in the magnetization of sediments. Rev. Geophys. 15, 129-143.

Watson, G.S., 1956. A test for randomness of directions. Geophys. Suppl. Mon. Notices Roy. Astron. Soc. 7, 160-161.

Whitney, D.L., Teyssier, C., Dilek, Y., Fayon, A.K., 2001. Metamorphism of the Centra Anatolian Crystalline Complex, Turkey: influence of orogen-normal collision vs. wrench-dominated tectonics on P-T-t paths. J. Metamorph. Geol. 19 (4), 411-432. 